\title{
Vass Balázs Ákos: „Mást tudnék csinálni, de hogy nem szeretném, az biztos!" Szociális munkások 2006-tól 2017-ig
}

\begin{abstract}
Absztrakt
Hogyan élik meg a szociális munkások munkájukat a mindennapokban? Milyen változásokon keresztül alakul a pályájuk? A válaszokhoz egy nagyváros 13 szociális munkásának megkérdezésével próbáltam közelebb kerülni 2006-ban és 2016-2017-ben.

Az interjúalanyok számos munkahelyváltáson és kisebb változásokon mentek keresztül. Többségüknél a munkával kapcsolatos attitüdváltozások voltak megragadhatók, kisebb részüknél tartósabb belső változások. Megfogalmaztak változásokat a szakma, a társadalom vonatkozásában is. Szinte mindegyikük úgy érzi, a szakmában el tudna helyezkedni akár a külső lehetőségek, akár személyes kvalitásaik miatt.

Az eredmények hozzájárulhatnak annak a pályaképnek az árnyalásához, melyről globálisabb információkat utoljára a képzés során kaptunk.
\end{abstract}

Kulcsszavak: szociális munkás, pályakép, változás, pályaszocializáció, szakmai identitás

\begin{abstract}
How do social workers see their work, their calling? What changes did they go through, and how did they value these? To have an answer, I interviewed 13 social workers of a city in 2006 and in 2016 and 2017.

The interviewees have already changed their workplace and gone through other changes in their life, which they experienced differently. Most of them showed alternations in their attitude toward their work, one-third presented prolonged changes in their internal thinking and personality. They sense and follow changes in their profession, and in the society. Almost all of them think that they have the opportunity to find a new job either up to their circumstances or their personal qualities.

The outcome of this research can contribute to the general opinion about social workers' career path, about which information is usually gathered during their studies.
\end{abstract}

Keywords: social worker, career, changes, career socialization opportunities, (professional) identity

\section{Bevezetés}

A diploma átvételétől szociális munkásnak hívnak bennünket. A föiskola, egyetem évei alatt jó esetben egyfajta erős szakmai szocializáción megyünk keresztül: a tapasztalataink hasonlóak, a szakmai identitásunk nagyjából azonos. Később munkát vállalunk, és a gyakorlatban különböző beosztásokba kerülünk: családsegítő, idősgondozó, hajléktalanellátó, esetmenedzser stb. Innentől kezdve azoknak a munkaköröknek a jellemzői és az azokon belül szerzett tapasztalatok határozzák meg a munkánk jellegét, minőségét. Az új munkakörre 
szocializálódunk, és a beosztásunk a folyamatosan változó tapasztalatok, élmények alatt kerül dinamikus kölcsönhatásba szociális munkás identitásunkkal és azt a folyamatos változások mentén tovább árnyalja, alakítja. De mi marad az eredeti szociális munkás identitásból? Mi a közös - a gyakorlatban - közöttünk? Mi változik meg feltétlen és hamar, és mi esetlegesen vagy hosszú gyakorlati tapasztalat után? Mi marad az évek során az eredeti „nyers” szakemberből? Mi az, amit a képzés során tanultakból az évek során hasznosítani tudott saját személyisége és a környezeti feltételek szabta kereteken, korlátokon belül -, mi az, ami látens maradt, és mi az a töredék, amit - mondjuk - később, egy munkakörváltás során mégis felszínre tud hozni, használni tud? Végül mi az a korábban elméletben oktatott tudás, amiről azt tapasztalta, hogy nem müködik, hamisnak tünik a jelen feltételek között? Egyszóval: a gyakorlat során mi marad „belölünk”? Hogyan látjuk - a sajátos munkatapasztalataink hatására - magát a gyakorlatot, az azt övező közvetlen és közvetett környezetet, a társadalmat? Mi változott körülöttünk, és miben változtunk mi ezek következtében?

Következzen egy idevágó részlet egy elkészült interjúból! „,..mondjuk nincs annyira köztudatban, vagy nem annyira ismert, hogy maga a szakma is - a sokszinüsége miatt - elég széttöredezett. Tehát hogy ki, mit tekint szociális munkának, és a maga szeméböl, és a maga intézményéböl kiindulva nagyon mást gondolhat egy idösgondozásban dolgozó szakember, vagy mondjuk nagyon mást egy pszichiátriai betegekkel foglalkozó, vagy mást egy gyerekjólétis. Nem is kell - azt gondolom -, hogy egyformán gondoljunk, mert hogy pont rengeteg-rengeteg oldala van, csak valamiféle közös pontokat is talán nehezen fogadunk el a másiktól. Valami ilyesmit érzek én ebben." (Zita, 37)

Kívánatos volna elsősorban megismernünk egymást, újra megismerni egymást mint szociális munkást. Ennek során megállapítani a közös pontokat, szempontokat - amelyek inkább összekötnek, közös jellemzők - azoktól, amelyek egyéniek, sajátosak. Miután a közös identitást, érték-, érdek- és szemléletbeli hasonlóságokat megfogalmaztuk, kialakulhatna, megerősödhetne a mi-tudatunk.

\section{A korábbi pálya- és szakmaképkutatásokról}

\section{Szakmatanulási modellek: a szakemberré formálás kezdetei}

Budai István 2007-ben a szociálismunkás-képzés főbb megközelítéseit veszi sorra, szem előtt tartva, hogy a szociális diplomások pályaelhagyására a képzésmetodika kérdéseinek tisztázatlansága is hatást gyakorolt. A személyiségfejlesztés fontosságát is aláhúzza, amikor Solomon elveit idézi: „a képzésnek nem elsösorban olyasmit kell megtanítania a diákoknak, amit nem tudtak addig, hanem olyan emberré kell alakitani öket, amilyenek nem voltak addig”, amely mind az Egyesült Királyságban, mind Németországban hatást gyakorol a képzésre (Budai 2007: 88). Összeveti a didaktikai és a tapasztalati tanulási modelleket, ahol az utóbbi több szempont alapján is dinamikusabbnak és korszerübbnek, müködöbbnek hat. Bemutatja a reflektív gyakorlat-reflektív képzést, mely a kritikus gondolkodás talaján müködik. A kutató-felfedezö tanulásirányítási stratégia alkalmazását előnyösnek tartja a szociálismunkás-képzésekben. A tradicionális egyetem és az interdiszciplináris egyetem összevetéséből az utóbbi mutatkozik hatékony képzési keretnek a szociálismunkás-képzés számára (Budai 2007: 84-109). 
A Partium területén több szociális és pedagógiai képzésben részt vevő hallgatót vizsgált Nagy Krisztina. Eredményeiből kiemelhetők a hallgatók szak-és iskolaválasztási stratégiáira; választott hivatásukról és a pályakezdésröl kialakitott elképzeléseikre vonatkozó válaszok, melyek alapján a szerző hallgatói csoportok karaktereit alkotta meg: céltudatos elkötelezett; próbálkozó; elcsábitott; eltévedt útkeresö; bizonytalan; kitartó; és szemlélödö érdeklödö. A 7 típus elnevezése érzékletesen utal a hallgató útjára (honnan jött, hová tart), attitüdjére a jelen és a jövő vonatkozásában. Azt találta, hogy a szociális képzésben több volt a „,bizonytalan” és „próbálkozó”, mint a pedagógusképzésben. Mindkét képzésben részt vevők körében hasonlóan rajzolódott ki egyfajta segítő pályaorientáció-pályakép. A pályájukhoz szükséges személyiségbeli összetevőket nagy arányban közösnek kommunikálták. Nagyobb eltérést a képzésről előzetes információ tekintetében mutattak, illetve a pedagógushallgatók világos, karakteres szakmaképével szemben a szociális hallgatók homályosabb szakmaképe állt. Karakteres terület szerinti eltérést is talált: „a Romániában és Ukrajnában élö, a magyarországi hallgatókkal sok tekintetben azonos társadalmi helyzetü, értelmiségivé váló fiatalok szemléletét sokkal inkább jellemzi egyfajta küldetéstudat, mint a hazánkban tanuló diákokét” (Nagy 2011: 113). Az eredmények alapján a képzés kiemelt szerepét fogalmazta meg a szakmakép alakulásában, alakításában (Nagy 2011).

A reflexiót Horváth-Lindberg Judit kiemelt fontosságúnak tartja, ennek talaján tud a (belső és külsö) dialógus megvalósulni, a terepen végzett szociálismunka-gyakorlat során. Szeretné a gyakorlatba beemelni a személyességet a megismerésben és a tárgy iránti elkötelezödést. A gyakorlat során hangsúlyossá válik a formális képzésen túlnyúló, ún. metatanulás: „A környezet, a munkahely légköre, esetünkben a gyakorlat helyszine magatartásokat, alapértékeket kinál fel, melyek elösegithetik vagy megakadályozhatják a tudás elsajátítását és $a z$ ismeretek megszerzését." Bemutatja a Reynolds által elkülönített szakmai fejlődési szakaszokat (öncentrikus - teljesitménykényszer - az egyéni szituáció megértése viszonylagos mesterségbeli tudás - saját szakértelem átadása), valamint felvázolja Rønnestad fejlődési modelljét (megerősités, lelkesedés - a komplexitás tudatossága, nyugtalanság összekuszáltság - összesités - integráció és realitásérzék). A gyakorlat hatékony integrálásának, feldolgozásának módját az ún. dialógusszemináriumban látja, amely a reflexiók használatán alapul (http 3).

\section{Az alapsokaság meghatározásának problematikája}

A magyarországi szociális munkásokkal foglalkozó kutatók már kezdetben egy alapvető problémába ütköznek. A Hányan vagyunk szociális munkások? kérdésből a Kit számítunk szociális munkásnak? kérdés következik, melyre több, igen eltérö eredménnyel és következtetéssel járó választ kaphat a téma iránt érdeklődő.

Kozma Judit szerint 1994-ben az arányok még meglehetősen rosszak voltak: „Ha azt kérdeznénk, hogy ténylegesen milyen ma Magyarországon a szociális munkás, akkor legelöször azt kellene megállapitanunk, hogy szakirányú képzettséggel nem rendelkezik (a képzettek oly elenyészö számúak, hogy nem tekinthetök tipikusnak)”(Kozma 1994:64).

Horváth Ágota és Lévai Katalin az 1996-os kutatási beszámolóban ekként reflektál a problematikára: „A továbbiakban sem teszünk különbséget a megjelölésben a felsőfokú szociálismunkás-képesitéssel rendelkezö szociális munkás, a középfokú végzettséggel rendelkezö szociális-asszisztens, a nem szociális végzettséggel rendelkezö szociális munkások 
és a legfeljebb egészségügyi szakiskolával rendelkezö házi szociális gondozók között" (Horváth, Lévai 1996: 55).

„Kit értsünk szociális munkáson, és kire terjedjen ki a vizsgálat? Azok kerüljenek-e bele, akiknek a végzettsége szociális munkás - függetlenül attól, hogy milyen munkakörben dolgoznak -, vagy azok, akik a szociális törvény által megnevezett intézmény- és feladattípusok szociálismunkás-státusait töltik be, a végzettségüktöl függetlenül?" - teszi fel a kérdést Fónai Mihály, Pattyán László és Szoboszlai Katalin 2001-ben, és végül az utóbbi csoportot fogadták el kutatásuk csoportjának (Fónai, Pattyán, Szoboszlai 2001: 89).

Nagy Krisztina látszólag egyszerü feleletet ad: „,szociális munkások mindazok, akik szociális munkát végeznek” (Nagy 2003: 28).

Talyigás Katalin és Hegyesi Gábor egy közelítő számról írnak a szférában dolgozók vonatkozásában: ,,1998-2002 között [...] a szociális szférában dolgozók száma megközelitette a százezres létszámot” (http 2).

Bass László Szociális munkások helyzete ma címü 2005-ös előadásában 5 ezer és 80 ezer fő között látta szóródni ezt a számot (http 1).

Szoboszlai Katalin számára is alapvető a kérdés: „, Megfejtésre várt 1990-ben és 2014-ben is a »ki a szociális munkás? " kérdés. [...] alig észrevehetö a diplomás szociális szakképzettséggel rendelkezök jelenléte a társadalomban. Az utolsó közzétett adat 2004-ben valamivel több, mint 12 ezer diplomás szociális szakembert jelzett [...] úgy vélem, 20 ezer diplomás szociális szakembernél nincs több az országban, és közülük sem találunk meg mindenkit a praxisban." (Szoboszlai 2014: 87-88)

A kérdéssel kapcsolatos zavar, többirányúság végigkíséri, áthatja a területtel foglalkozó szakemberek, publikációk és a szociális területen dolgozók nézőpontjait is, ami meghatározó hatással lehet arra, ahogyan a szakma gondolkodhat saját magáról. Az identitásformálódásnak e kérdéskör letisztulása segítségére lehet.

A szociális munkásokra irányuló hazai kutatásokról

Az alábbiakban néhány olyan kutatást sorolok fel, amelynek alanyai a hazai szociális munkások voltak. Nagyobb ívü kutatásokról lévén szó, az eredményekből, megállapításaikból csupán néhány mozzanatot említek meg.

Horváth Ágota és Lévai Katalin kutatásukban - melyet 1996-ban publikáltak - a különböző intézményekben dolgozó szociális munkások családi hátterét, iskolai és munkaútját, munkamódszereik és azok változásai a szociális ellátórendszer változásának tükrében, a szociális munkások szakmai identitását, valamint a leggyakrabban felmerülő problémák és konfliktusok témaköreit vizsgálták. Az egyik kutatói kérdésük: ,e nagyon különbözö képesitésü emberekböl összeálló szakmának mi ad mégis belsö kohéziót (ha van ilyen)", (Horváth, Lévai 1996: 35). 
Egyik konklúziójuk: „A bemutatott élet- és munkautak azonban megerösitik a korábban mondottakat: a szakma rövid múltja, a szociális képzés korábbi hiánya, valamint a szakma alacsony elismertsége együttesen azt eredményezte, hogy szinte bárkiböl, bármilyen iskolai és munkaelözmény után lehet-lehetett szociális munkás" (Horváth, Lévai 1996: 55).

Fónai Mihály, Kiss János és Fábián Gergely 1997-ben szociális munkás szakos hallgatók pályaképét vizsgálták. Eredményeikböl: „Az alacsonyabb társadalmi presztízs általában alacsonyabb érdekérvényesitési képességgel és hatalommal jár együtt, igy a hallgatók rangsora szerint a szociális munka társadalmi presztízse és érdekérvényesitó képessége, valamint hatalma alacsony” (Fónai, Kiss, Fábián 1999: 129); „a megkérdezett hallgatók pályaképét jelentös mértékben a szociális munka mai magyarországi újszerüsége és a szakmára generálisan jellemzö segítö-attitüd és az azzal összefüggö értékek alakitják”" (Fónai, Kiss, Fábián 1999: 131).

Győri Péter 1996-ban számolt be az ELTE „szociális, szociálpolitikai” levelező tagozatán végzett kutatásról. A kutatásig végzett hallgatók köréből (178 fö) 58 értékelhető kérdőívet kapott vissza. Települési, származási mobilitás, munkahelyi mobilitás, munkavégzéshez kötődő motivációk, aspirációk, az oktatás helye, szerepe a szakmai orientációban, a pályaút alakulásában és karriertípusok, és az iskola témakörökben vizsgálódtak. „,...válaszadóink motivációi egyfajta mérsékelt, de határozott szakmai elhívatottság képét mutatják számunkra" (Győri 1996: 65).

Pék István Merre tovább szociális munkások? címü dolgozatában az ELTE Bárczi Gusztáv Gyógypedagógiai Főiskolai Karán 1994-1998 között 5 évfolyamán végzett szociális munkásokat kérdezte a szakmában maradásról és a pályaelhagyásról. Többek között azt találta, hogy a szociális munkások a munkájukban, a munkahelyükön a klienseket, a kötetlen, rugalmas idöbeosztást és az érdekes, sokszinü munkát szeretik. Nem szeretik: a kiégés veszélyét, az alacsony jövedelmet, kevés juttatást, valamint a bürokrácia „útvesztöit”. A pályaelhagyás legfontosabb dimenziói: a fizetés, a pszichés leterheltség és a megváltozott érdeklödés (Pék 2000: 105-118).

Fónai Mihály, Pattyán László és Szoboszlai Katalin 2001-ben azokkal a szociális munkásokkal kapcsolatban végeztek kutatást, akik a szociális törvény által megnevezett intézmény- és feladattípusok szociálismunkás-státusait töltik be, a végzettségüktől függetlenül. „A megkérdezett szociális munkások pályaképének fö jellegzetessége a pályaválasztás elötti és utáni szakmai motivációk és preferált értékek közötti lényeges különbség. Általában véve meglehetösen ambivalens pályaképröl van szó, amit részben a professzionalizáció ellentmondásai, részben a szakmával összefüggö ellentétes elvárások és a szakma sajátosságai alakitanak. [...] Szakmai szerepkészletük központjában a kliens található." (Fónai, Pattyán, Szoboszlai 2001: 108).

Nagy Krisztina 2003-ban a szociális munkások pályaorientációjával kapcsolatos, addig elvégzett hazai (és részben külföldi) kutatások eredményeit vetette egybe, összegezte (Nagy 2003: 27-47).

Pilinszki Attila, Béres Orsolya, Sipos B. Bernadett, Ittzés Gábor: Mit értékelnek a szociális munkások címmel 2014-ben publikálták, melyben a Semmelweis Egyetem Egészségügyi Közszolgálati Kar Mentálhigiéné Intézete 5 évfolyamának hallgatói körében kérdőíves értékkutatást végeztek. Egy fontos megállapításukról: „A szociális munkások értékrendjében vezetö szerepet töltenek be a belsö és kapcsolati értékek, míg az anyagi és élvezeti értékek 
inkább háttérbe szorulnak. [...] Az elöitéletmentesség, a hatékonyság, az alkotó szellem és a logikus gondolkodás négyese rajzolódott ki.” (Pilinszki és mtsai. 2014: 91)

\section{Kutatási területem}

A szociális munkásként végzett, szociális munkásként dolgozó szakemberek pályaképe, pályaútja, illetve azok időbeli változásai érdekelnek. Fontos az összes munkával kapcsolatos lehetséges körülmény, és hangsúlyosak a szakember ezekkel kapcsolatos beállítódásai, viszonyulásai, élményei, kognitív és érzelmi reflexiói, valamint azok az összefüggések, melyeket e körülmények között a szakember lát.

Fontosnak tartom ugyanakkor az interjúalanyok szociodemográfiai hátterének felvázolását és a munka körülményeivel kapcsolatos objektív mutatók meghatározását is - amelyek hatással lehetnek a szubjektív élményre - a mérhetőség, összehasonlíthatóság végett.

Az értékelő- és élménytermészetü kérdések hangsúlyából következően a kvalitatív, interjújellegü kutatási módszereket részesítem előnyben.

\section{A jelenlegi kutatásról}

\section{A kutatás közvetlen elözménye}

2006-ban a szociális munkások pályaútját, pályaképét, pályaperspektíváját, valamint az ezeket kísérő élményeket vontam a vizsgálódás középpontjába, különös tekintettel a szociális ellátás eltérő szegmenseit ellátó intézményekben, más-más munkakörben dolgozók különbözőségeire. ${ }^{1}$ Érteni, értelmezni szerettem volna a gyakorlati szociálismunkás-szerepet, annak élményét, alapkutatás-jelleggel.

Szociális munkásnak azt tekintettem, aki olyan beosztásban dolgozik, ami felsőfokú szociális képzettséghez kötött, és szociálismunkás-diplomája van, illetve végzős. E személyi kör tagjai - mely két fontos tényező: a szakmakép és a szakmai önmeghatározás erős kiinduló alapjai lehetnek - hasonlóbban élhetik át a képzés és a gyakorlat kettős hatását. A kérdésekre egy magyarországi nagyváros szociális munkásainak megkérdezésével próbáltam meg választ kapni. Az alapsokaságból (34 fö) munkahelyenként véletlen mintavétellel választottam ki 13 szociális munkást. A minta összetétele kor, nem, föiskolai/egyetemi végzettség, nappali/levelező képzési forma, képzőintézmény, ágazat, beosztott/vezető szempontok szerint viszonylag heterogén lett. 13, önként vállalkozó szociális munkással félig strukturált interjút készítettem.

\footnotetext{
${ }^{1}$ Érdeklődésem hasonló ahhoz, amit előttem mások már frappánsan fogalmaztak meg: - „Kik is azok a „,szociális munkások? [...] Kik ők, és honnan jöttek (merre tartanak)?” (Győri 1996: 57); „kik azok, akik ezen a pályán dolgoznak, milyen motivációk, illetve kényszerek vezették őket szakmaválasztásuk során, milyen iskolai és családi háttér jellemző rájuk, és melyek azok az értékek, amelyek döntő szerepet játszanak szakmájuk gyakorlásában" (Horváth, Lévai 1996: 71).
} 
2006-ban a pályán dolgozó szociális munkásokról szerettem volna tudást szerezni, többek között az alábbi föbb kérdések merültek fel bennem:

Kik a szociális munkások?

- Milyen szociodemográfiai, szociokulturális jellemzőkkel bírnak, milyen családból származnak?

- Hogy alakult a pályájuk, pályaképük?

- Melyek a beválás, melyek a siker kritériumai a szakmában?

- Hogy látják a munkát, a klienseket, a szakmát és szakemberként a világot?

- Hogy érzik magukat a munkában?

- Milyen konfliktusaik, milyen problémáik vannak? Mi foglalkoztatja öket?

Az interjú ezen kérdések tekintetében volt strukturált.

Várakozásom az volt, hogy ezen kérdés- és témakörök mentén - melyek „lefedik” a gyakorló szociális munkásság lényegét - halad majd a megkérdezés, és ezeket a szakemberek a saját gondolataikkal, érzéseikkel egészítik ki, melyeket a kérdező a mélyinterjú irányába terelne.

Az interjúk kezdetén azt tapasztaltam, hogy e kérdések sorozatának feltevése (és azok gépies megválaszolása) csapongóvá, töredezetté teszik az interjút, távolítják az interjúalanyt a kérdezőtől, a mélyebb válaszokat gátolják. Csökken a spontán önkifejezése, és a válaszok némiképp szükszavúak, sztereotipek vagy védekezőek, hárítóak lesznek. A beszélgetések saját dinamikája az előre megfogalmazott kérdéseket esetlegessé, fluktuálttá tette, így statisztikai feldolgozásra alkalmatlan válaszgyakoriságot kaptam. Ez a fajta információszerzési modell - a segítő szakemberek személyes nézőpontú megkérdezése tekintetében - túl strukturáltnak, zsákutcának bizonyult.

Indirektebb témamegközelítésre váltva - a kontrollt bizonyos tekintetben átadva az elbeszélőnek - mindinkább az élmény került a közlés és a figyelem fókuszába. A mondanivaló lényegét az interjúalanyok jelenítették meg tehát, és az ő csomópontjaikat, az azok közötti összefüggéseket ők fogalmazták meg, értelmezték, reflektáltak saját magukra. Az így kapott szöveg nem vált összehasonlíthatóvá csak önmagával. Hallgatva, látva a tapasztalatok, élmények és vélemények ,,áradását”, túlnyomórészt azt tapasztaltam, hogy a kollégák erös szükségét érezték és érzik a maguk - és környezetük - szakmai megfogalmazásának, kifejezésének és újragondolásának.

A beszélgetések átírásából nagy szövegegységek születtek, melyeket elsődleges tartalomelemzésnek vetettem alá, így sikerült a válaszadók segítő karakterét felvázolnom. A szakemberek által elmondottak sajátosak, a közlések egyediek és sokszor frappánsak voltak, hogy azok feldolgozás nélküli, ámde szerkesztett megjelentetésére is alkalmasnak tüntek úgy a szakma, mint a köz számára.

Az interjúkat - a válaszadók védelmében és kifejezett kérésére - szó szerinti átírás után anonimizáltam, hiszen a közlések sokszor bizalmasak voltak: kényes érzéseket, gondolatokat, belső ambivalenciákat vagy külső konfliktusokat fogalmaztak meg. (Az interjúk folyamában felvázolódó összefüggések miatt a városra regionálisan is következtetni lehet. Ez az érintettek egyértelmübb beazonosíthatóságát tenné lehetővé, ezért az anonimizálás a földrajzi nevekre is kiterjedt.) 
A kutatásról 2006-ban a Pécsi Tudományegyetemen elkészített szakdolgozatban számoltam be. A „KI AKAR MÉG DUDÁS LENNI?” címü dolgozat dr. B. Erdős Márta segítségével készült. Jelen kutatás kiindulópontjai tehát a 10 évvel korábbi interjúk szövegei, valamint azok feldolgozása.

Amióta az interjúk részleges megismétlésének és a korábbi anyag részleges újrafeldolgozásának gondolata megfogant bennem, dr. Piczil Márta kíséri a munkámat hathatósan. Csakúgy, mint a 2004-ben elkészített „Sokat fogok tanulni az emberektöl...” címü, főiskolai szakdolgozat megírása során, amelyben a szociális munkás szakra jelentkezők szociodemográfiai felmérésére és pályaorientációs vizsgálatára tettem kísérletet.

\section{A kutatás célja}

„Képesek vagyunk-e elmondani, mi a szociális munka?” - kérdezte Szoboszlai Katalin 2014ben, újabb alkérdéseket vetve fel: „Mint látjuk, nem tisztultak le azok a narrativák, melyek világosan megfogalmazzák a társadalomnak a szociális munkát és a szociális munkások karakterét. [...] elöre azzal léphetünk, ha közérthetővé tesszük, megjelenitjük a szociális munkást, a szociális munkát a társadalomban. Példaképekre, szociálismunkás-történetekre, a professziót valóságosan ismertetö megjelenésre édesvizként van szükségünk, kiemelve a szakma és a szakemberek olykor lázadó, újitó, máskor együttmüködö és minden esetben segitö jellegét." (Szoboszlai 2014: 88)

Szerettem volna megtudni, hogy a 10 évvel korábbi interjúalanyaimnak a korábbi interjúk óta hogyan alakult a pályájuk, a szakmai sorsuk, a munkában milyen hatások érték őket. A munkában mely tényezők és mennyiben változtak velük kapcsolatban, körülöttük.

A 2016-2017-ben megismételt interjúk standardizált kérdéseivé a változástípusú kérdések váltak, e tekintetben kvantitatívabb összehasonlítást lehetővé téve. Kizárólag a változástémakör kérdéseit tettem fel minden esetben, a többi kérdéskör tekintetében kapott válaszok szórványosak. (A változás témakörén túlmutató, a szociális munkások teljesebb bemutatására alkalmasabb interjúrészek egy következő tanulmány megírásának lehetőségét vetítik elöre.) Változásnak azt tekintettem, amit 2016-2017-ben akként említettek, értékeltek a válaszadók.

A szociális munkások által elmondottak ezúttal is sajátosak, a közlések egyediek és frappánsak lettek, az így keletkezett szövegek véleményem szerint önmagukban alkalmasak lehetnek a terepen dolgozó kollégák bemutatására. Fontosnak tartom, hogy mi, szociális munkások egymásnak megmutathassuk, milyenek vagyunk, milyen a munkánk (ez a cél kiemelt lehet a pályaszocializáció folyamatában, a képzés során). Az hogyan hat ránk, mi ad erőt, és mi kedvetlenít el.

A tágabb témáról - hogy tudniillik Milyen élmény szociális munkásnak lenni, akként élni? egy olyan tanulmányt szerettem volna írni, amely - amennyire csak lehetséges - hủen adja vissza, jeleníti meg az interjúalanyok által tapasztaltakat, elmondottakat. Segítő szakemberként számomra a szándékosan megfogalmazottak mellett a látens tartalmak, ambivalenciák feltárása, egyszóval a 'szöveg mélye' igazán érdekes és izgalmas kiegészítés lehet. Ezek helyenként megerősíthetik a direkt közléseket, másutt belső ellentmondásokra világíthatnak rá. Az interjúalanyoknak elsősorban az általuk elmondott szándékolt, direkt tartalmak leírását, közlését és elemzését ígértem, amit igyekeztem szem előtt tartani. Ha „csupán” ezekről a mindennapok közvetlen tapasztalataiból származó direkt, manifeszt tartalmakról indulna be egyfajta szükebb vagy tágabb párbeszéd, az már nyereség lenne. 
Jelen tanulmányban kizárólag a változásokra és azok lehetséges aspektusaira térek ki.

\section{A vizsgálat körülményei}

2016-ban a korábbi interjúalanyok közül 2 fő nem vállalta az újabb interjút (egy fö tartósan külföldön él, 1 fö a munkahelye miatt nem akart nyilatkozni). Emiatt 2 további interjúalanyt vontam be. A heterogenitást szem elött tartva jutottam el két újabb alanyhoz: az egyik pályakezdő, a másikuk pedig egyetemet végzett, cigány nemzetiségü. Egyik családsegítőként, a másikuk esetmenedzserként dolgozik.

A korábban értékelhető válaszgyakoriságot nem eredményező kérdéseket ezúttal az interjúkból kihagytam. A korábbi interjúk így kijelölték, leszükítették a témák körét. A tematikusan immár „letisztultabb” interjúk érzésem szerint tartalmilag mélyültek.

Az interjúalanyok és a kérdező - „hétköznapi szociális munkások”, amennyiben nem feltétlenül: szakértők / tereptanárok / oktatásban részt vevők / vezetők és más tekintetben sem kiemelt reprezentánsai a szakmájuknak, szakterületüknek. Ha a megkérdezett ún. szakértő, és a kérdező nem, az az interjúhelyzetben egyébként is meglévő aszimmetriát fokozhatja, akárcsak fordítva. Ez kontrollált-kontrolláló helyzetet alakíthat ki, az interjúalany megnyílását csökkentheti, és a beszélgetés dinamikáját egyrészt a kontroll fokozása, másfelől az aszimmetria csökkentése felé terelheti. Ezek a dinamikák pedig az információszerzést torzítják. A problémák tehát annál kevésbé merülnek fel, minél kevesebb aszimmetriára utaló körülményt tapasztalhatnak a résztvevők. A másik fontos előfeltétel a garantált anonimitás volt, amely a megnyílást, feltárást segítette, valamint az intimitás, a „,problematikus” és az ambivalencia felvállalását támogatta.

\section{Az adatfelvétel módszere}

Érdeklődésem jellegének leginkább az Irving Seidman által ajánlott, hármas tagolású (fókuszált élettörténet, élmények, majd az élmények értelmezése) fenomenológiai mélyinterjú felelt volna meg, amely a gyakorlatban 3 leülést jelent az interjúalanyokkal (Seidman 2002). 2006-ban a válaszadók beleegyezése 1 alkalomra szólt, így az interjúk 1 leülésben történtek, amelyeknek kivitelezése, átírása és feldolgozása - viszonylag rövid idő alatt - sok tekintetben a kutatói lehetőségeim határát jelentették. Ezért a félig strukturált interjúmódszer mellett maradtam.

2017-ben a fenti törekvéshez kicsivel közelebb kerültem. Az interjúalanyok vállalásából következően - hat interjú 1, öt interjú 2, valamint egy interjú 3 leülésben történt. Bár 10 év eltelt, de az új interjúk dinamikailag érezhetően folytatólagosnak, egymásra építkezőnek tüntek. Így több esetben a kívánatos, 3 leülés összességében mégis megtörtént. Ezúttal több volt a személyesebb élmény, több szociális munkás reflektált magára, a helyzetére, a történetére.

Az eredmények elé: a nem laikus olvasó olykor úgy érezheti, hogy a dolgozatban közhelynek tünő közlések, következtetések, megállapítások is vannak (noha én sohasem minősíteném annak interjúalanyaim szövegeit, és az azok mögött lévő mély, egzisztenciális tapasztalatokat). Ezek az ismerősnek tűnő információk ilyen minőségükben mégis sok tekintetben validálhatják a már tanultakat, tudottakat, az ifjabb, szakma iránt érdeklődőket pedig egyfajta gyakorlatból származó visszacsatolásként orientálhatják. 
Kutatásom alapsokasága, a minta mérete, nem reprezentatív volta, az adatfelvétel módja és nem utolsósorban a jelenlegi tanulmány témája összességében kevés összehasonlítási alapot adnak az igényében, kíváncsiságában egyébként igen hasonlónak tünő kutatásokkal. Ez a tény indokolhatja, hogy a vizsgálat eredményeit csak helyenként, az adatok szük keresztmetszetén tudom összevetni más kutatások megállapításaival.

\section{Kérdések}

Az interjúalanyoknak a változás témakörben 5 kérdést tettem fel, melyek segítségével az őket érintő változásokat igyekeztem minél teljes körübben megragadni: a múlt és a jelen vonatkozásában.

- „Mi történt veled a 10 év alatt?” (Milyen hatások érték?)

— „Miben változtál a 10 év alatt?” (Az őt ért külső hatások révén miben változott?)

- „Hogyan látod, miben változott a szakma az évek alatt?” (Közvetett változások)

- „Minek kellene ahhoz történnie, hogy azt mondd, hogy köszönöm, ennyi volt?” (Melyek azok a személyes határok, keretek és hatások, amelyek között még hajlandó dolgozni, és amelyeken túl már változtatna?)

— „Ha úgy adódna, tudnál máshol dolgozni?” (Az észlelt munkaerőpiaci lehetőségek: a változás lehetőségei a jelenben)

\section{A válaszadók}

9 nő és 4 férfi az interjúk alanya. A legfiatalabb 30, a legidősebb 64 éves. Legtöbbjük a gyermekvédelemben dolgozik, de megjelenik közöttük a hajléktalan-, az idősellátás vagy a szenvedélybeteg-segítés. Van közöttük ifjúságsegítö, addiktológiai szakember és gyermekotthoni nevelö, valamint család- és párterapeuta is. Akad olyan is, aki a gyermekvédelemben dolgozott sok évet, és immár családi vállalkozásban dolgozik (nem segítő területen).

\section{A válaszadók egyenkénti bemutatása}

A válaszadókat a 2006-ban elkészült szakdolgozatban egyenként mutattam be, rájuk jellemzőnek tünő idézetekkel kiegészítve. Ezekböl igyekeztem egy rövidített, tömörebb betekintést adni, amely reményeim szerint képes megvillantani azt a spontán sokszínüséget, amelyet a szerencsésebb interjúkészítők tapasztalhatnak meg a találkozások és beszélgetések során.

Az egyenkénti bemutatás második részében igen röviden, címszavakban vastagon szedve a kollégák jelenlegi helyzetét mutatom. A bővebb újbóli bemutatás helyett a változásról - a nagy szövegegységek helyett - a feldolgozás megállapításai beszéljenek.

Következzen az interjúalanyok egykori és mai bemutatása. 
Márk a 20-as évei végén járó szociális munkás, két hónapja dolgozik a hajléktalanelláásban, és az idén diplomázik a föiskola levelező képzésén. A szakmunkásképző után 4 évig egy közel-keleti országban szerzett különféle munkatapasztalatokat - ott jött rá, hogy tulajdonképpen humán beállítottsággal rendelkezik. Utána itthon egy szociális otthonban dolgozott 3 évig, ápolóként. Közben leérettségizett, szociális ápolói-gondozói képesítést szerzett. Az érettségit követően rögtön sikeresen felvételizett a szociálismunkás-képzésre.

Véleménye a szakmáról: „Ennek a szakmának presztízse, megbecsülése abszolút nincs [...] a társadalom számára nincsen. Azt sem tudják mi ez, és ez évekig igy is fog maradni. Ez mindig probléma, ezt a szférát erösiteni kellene, ha meg lehetne fizetni, akkor a szakmának lesz presztizse. [...] ez szociális szféra -, ahol abszolút a források egyre kevesebbek lesznek."

Márk ma 39 éves mentálhigiénés szakember, 10 éve hajléktalanszállón dolgozik, ezen belül 5 éve átmeneti és rehabilitációs szállón szociális munkás. Több müszakos munkarendben dolgozik, a pótlékokkal együtt havi nettó 165000 forintért. A szabadidejében - heti 20 órát - karitatív szervezetnél önkénteskedik. 8 éve diplomázott. Az élettársával 2 gyermeket nevelnek.

Zita 2 éve végezte el az egyetemet. Azóta az idősgondozásban dolgozik mint szociális és mentálhigiénés munkatárs. Az egyetem elött egészségügyi szakiskolába járt, majd leérettségizett. Jelenleg területi gondozást végez, egyéni esetkezelést végez, illetve esetmegbeszélést a kollégáknak több telephelyen. Emellett az idősek akadémiáját szervezi, pályázatírásban is részt vesz. Félállásban egy hajléktalan-ellátó intézményben dolgozik, ahol 14 szociális munkás kollégája van. A velük való kommunikáció, kapcsolat sokat segít Zitának.

Zita 37 éves, szakmai vezető egy szenvedélybeteg-segítő nappali intézményben. 12 éve dolgozik szociális területen. Havonta 185000 forint körül keres nettóban. Egyedülálló.

Júlia 33 éves, szociális munkás végzettségú családanya. Még nem diplomás, mert a nyelvvizsgája hiányzik. Korábban szociális asszisztensként 2 évig vezetett egy idősek klubját. Jelenleg egy uniós program keretén belül dolgozik, tartós munkanélküliek munkába állását segitő mentor. A helyi szociális alapellátás foglalkoztatja - mint szociális asszisztenst közhasznú munkásként. A szociális munka nehézségét abban látja, hogy nem mérhető, és ha van is eredmény, az nem látszik mások felé: gyenge a transzparenciája. Más vonatkozásban a sikerélmény hiányzik.

Júlia 43 éves gyermekotthoni nevelö, otthonvezető fél éve. 15 éve dolgozik a szakmában. Havi nettó 175000 forint a jövedelme. A férjével 2 nagyobb gyermeket nevelnek. 
Hajnalka 33 éves addiktológiai konzultáns. A főiskola elvégzése után egy bentlakásos drogrehabilitációs otthonban dolgozott, 8 évig. A „rehab”-on, mint első munkahelyen, szerzett munka különösen meghatározó és megrendítő volt számára.

Jelenlegi munkája alacsony küszöbủ szociális ellátás. Most az ártalomcsökkentő program tartozik hozzá. A börtönben folytatnak egészségfejlesztést és csoportprevenciót fiatalokkal, akiknek alkohol-, játék- vagy kábítószer-függőséggel kapcsolatos problémájuk van. Az egyik föiskolán - külsősként - harmadéveseknek addiktológiai szemináriumot tart, valamint drogügyi koordinátorképzést csinál Zánkán. Tapasztalata a kiégésről: „, a Rehab utolsó éveiben teljesen ki voltam égve!”. A kezelörendszerben ,,mindent” bejárt. A jelenlegi sokrétü munka jó hatással van rá: „,szerintem én ezek miatt nem vagyok úgy igazából kiégve”.

Hajnalka most 43 éves szociális munkás. Pályázatokban, képzésekben dolgozik, esetmegbeszéléseket tart, és civil szervezetekben munkálkodik. Van fóállása, mellékállása és több megbízása. Havi nettó 300000 forintot keres, de tréningek esetén még 100000 forintot. Az élettársával 1 gyermeket nevelnek.

Dezső a harmincas évei elején járó szociális munkás, ifjúságsegitő. 12 éve van a pályán. Korábban, a szociális szférában (családsegítö, gyermekjóléti szolgálat) közel négy évet dolgozott, a jelenlegi munkahelyén összesen 8 évet. A pályára polgári szolgálatosként került az érettségit, illetve a cukrász szakmunkásképzőt követően.

Szakmai identitása átalakulóban van: a szociális munkásból fokozatosan ifjúságsegítő válik, ami azt jelenti, hogy az elöbbi dominanciája csökken. A szociális munkásokkal kapcsolatosan sok teendőt lát: , képviselhetnék magukat erösebben [...] attól, hogy szegényekkel dolgoznak sokszor, vagy a társadalom perifériáján levö csoportokkal, akiket lebecsülnek, azért még magukat nem kellene lebecsülni. Lehetnek magabiztos, erös emberek, akik szakértöik munkájuknak, akik képviselik önmagukat [...] Jó volna egy erös szakmai identitással levö csoportot látni. [...] kliens-központú legyél, célzottan használj rendszereket, és ne szolgáld ki a hatalmat.” A kiégés kapcsán: „, mintha lemondanának ezek az emberek valami fontosról, a saját magukkal való törödésröll".

A 42 éves Dezső ifjúságsegítő szakember, 22 éve dolgozik szociális területen. 4 ifjúsági közösségi teret szakmailag irányít, valamint az ifjúsági önkéntességet szervezi. Szükség esetén tart iskolai felkereső foglalkozásokat, valamint fejlesztő foglalkozásokat iskolákban és iskolán kívül is. A foóllásában havi nettó 128000 forint fizetést kap. Maradt a másodállása, egyéni vállalkozó. Az élettársával 2 gyermeket nevelnek.

Flóra 35 éves, gyermekjóléti szolgálatnál családgondozó. Ápolónőnek tanult, majd dolgozott 7 évig. A munka közben végezte el a szociális munka szakot. Utána egy rövid ideig családsegítő szolgálatnál dolgozott, majd hamar átkerült a jelenlegi munkahelyére. Szociális munkásként 9 éve dolgozik.

A kompetenciahatárait keményen tartja. Az évek alatt kialakított személyes gondozási stílusa a munka könnyüségét jelenti neki. Attól tart, éppen a kiégés folyamatában van. Ez a bizonytalanság megterheli, a szakmával kapcsolatos gondolatvilágát is átszínezi. 
Javaslata a gyakorlatban dolgozó szakemberek számára: ,jól érezzék magukat a börükben [...] azon a munkahelyen, ahol vannak, amit csinálnak. [...] kapjál valami pozitív élményt, hogy nevess valakivel. [...] egészséges személyiség maradj, attól független, hogy ezt a munkát végzed, hogy ennyi negatív valamit szedsz magadra. Vagy úgy, hogy több a szabadságod, vagy úgy, hogy valami olyan programot kapsz."

A 45 éves, szociális munkás végzettségü Flóra ma Svájcban él. A férjével egy családi cukrászvállalkozást csinálnak: tortákat készítenek. 2 gyermeket nevelnek. A jövedelme változó, illetve nem elkülöníthetö.

Andrea középkorú, kétgyermekes hölgy, aki az idősek otthonában foglalkoztatásszervező, mentálhigiénés csoportvezetö-helyettes. 12 éve dolgozik az intézményben. Az érettségi után csecsemő-gyermekgondozói képesítést szerzett, ám a gyes után az idősgondozást választotta. '96-ban szociális menedzser-intézményvezetői képesítést szerzett. 2 éve szerzett föiskolai diplomát. A család és a tágabb család jelenti számára a mindennapok hajtóerejét. Azonosít magában egy, a vezetés felé továbblépés iránt motívumot, mely a szakmai fejlődés szükségletéből és a változatosság iránti igényböl fakadnak.

Andrea ma 58 éves telephelyvezető az idősgondozásban. 23 éve dolgozik az idősellátásban. A férjével 40 éves házasok lesznek, 2 felnőtt gyermekük van. A jövedelme nem ismert.

Gyula a családsegítő szolgálat vezetője, ahol már 15 éve dolgozik. Előtte 10 évig a KÖJÁL-nál, majd egy nagyüzem mérnökeként vállalt munkát. A szociális szférát megelőzően is foglalkozott emberekkel: jegyeseket oktatott, nagycsaládosok egyesületében tevékenykedett, erdélyi menekültekkel foglalkozott. A szociális munkás végzettséget 2005ben szerezte meg.

A családsegítést az egyik legszínesebb, változatos és felelősségteljes munkának tartja, mely azonban sokszor harc. Harc a sok szociális probléma mellett, konfliktus a magát rászorultnak feltüntetni akaró emberekkel vagy szakmaiatlan elvárásokkal szemben.

„Az egyik politikusunktól hallottam: A ti dolgotok az, hogy az embereket, akik a társadalom szemében szálka - tehát a hajléktalan, cigány, szociálisan hátrányos helyzetü valaki -, ezeket dugjátok el a társadalom szeme elöl, és akkor jól végeztétek a munkátokat, ha ezeket sikerül eldugni! Erre volt az én válaszom, hogy én meg nem azért dolgozom, hogy eldugjam ezeket az embereket, hanem hogy olyanná tegyem öket, hogy a társadalom szemében ne legyenek szálkák!” A kliensekben a segítőröl kialakult kép teljesen hiányos, torz, kevéssé árnyalt: „, $a$ szociális és a szocialista fogalmakat összekeverik. Megkérdeztük, hogy ki a családgondozó, és akkor azt mondta, hogy a feleségem gondozza otthon a családot."

A 64 éves Gyula a nyugdíj mellett család- és párterápiát végez a családsegítő szolgálatnál - immár 4 éve. A feleségével él, 18 unokájuk van. A jövedelme nem ismert. 
Rudolf 5 éve dolgozik szociális munkás és szociológus végzettségüként egy gyermekjóléti szolgálatnál. Dolgozott szenvedélybetegek melegedőjében, drogrehabilitációs otthonban, családsegítő szolgálatnál és munkaügyi központban is.

A gyermekvédelmi munka légkörét nehéznek írja le: ,életekröl döntünk, vagy kellene döntenünk, javasolni, hogy most családban maradjon, vagy ne maradjon [...] állandó feszültséget jelenthet mindenkinek, aki itt dolgozik". A munkahelyén leginkább a csapat miatt érzi jobban magát, a közeg erősíti, a problémák ellenére is. Itt 2-4 évig, a családsegítésben még 8 évig tudja elképzelni magát. Utána ezt a 'szálat levarrná': informatikával és borászattal foglalkozna, élete végéig.

Rudolf, a 45 éves szociális munkás és szociológus végzettségü kolléga családsegítőként dolgozik. A családsegítő szolgálatnál 4 éve, szociális területen összesen 14 éve dolgozik. A jövedelme havi nettó 148000 forint. Élettársi kapcsolatban él.

Emma 34 éves családanya, gyermekfelügyelő egy gyermekotthonban. Korábban vendéglátásban, majd egy ügyfélszolgálaton dolgozott. A szociális munkát, szférát nem ismerte - az első találkozás a föiskola volt -, és az akkor elkezdett új állás a szociális étkeztetés területén. Az ott tapasztaltak, a kliensek megérintették: ekkor tudatosult benne, hogy emberekkel szeretne foglalkozni. A gyermekek átmeneti otthonában ellátott gyermekek sokszor „megérintik”, óhatatlanul közelebb kerülnek hozzá.

Emma a negyvenes évei közepén járó szociális és mentálhigiénés munkatárs, részlegvezető egy hajléktalanok szociális otthonában. A vezetői és müszakpótlékokkal együtt havi nettó 164000 forintot keres. Házas, 2 felnőtt gyermekük van, sốt unokájuk is.

Katalin 36 éves családanya, családgondozó egy egyházi fenntartású családok átmeneti otthonában, előtte diplomázott. A szakma mindig is 'közel volt hozzá', hiszen édesanyja a családsegítő szolgálattól ment nyugdíjba, ahol 10 évet dolgozott. Érettségi után több képesítést is szerzett, több szakmában dolgozott: volt titkárnő, kerámiaformázó (miután egy ilyen iskolát elvégzett), gyüjteménykezelő egy múzeumban, majd hivatásos gondnok.

Katalin 46 éves lakásotthoni nevelö. 12 évet dolgozott szociális területen, 11 éve diplomázott. 160000 forint a jövedelme. 2 gyermeke felnőtt, 2 kisgyermeket nevel.

Erzsébet 2006-ban fogyatékos- és idősellátásban dolgozott, majd speciális gyermekotthonban.

Erzsébet, a 44 éves, cigány nemzetiségú családsegítő egy család- és gyermekjóléti központban dolgozik, 2 éve. Most a gyermekvédelmi szakellátásban talált állást. Élettársi kapcsolatban él, egy 20 éves gyermeke van. A jövedelme nem ismert. 
Rebeka 10 évvel ezelött főiskolai hallgató volt.

Rebeka 30 éves esetmenedzser. 7 éve végzett a föiskolán, 2 éve dolgozik. A munkája mellett kapesolatügyeletet is végez. Masterképzésbe is jár. 2 kisgyermeket nevel egyedül. A havi 186000 forintos nettó jövedelmét az ügyeleti pénzzel egészítette ki.

\section{Az eredmények ismertetése}

Külsö hatások

„Mi történt veled a 10 év alatt?”

Azokra a lényegesebb hatásokra voltam kíváncsi, amelyek az interjúalanyokat az eltelt időszak alatt a munkával kapcsolatban érték. Minden interjúalanyt számos változás ért a munka vonatkozásában. Itt a föbb változásokat veszem számba.

Munkahelyváltás

A tényleges munkahelyváltások mellett azokat a típusú változásokat is idesoroltam, amikor bár a munkakörében maradt a válaszadó, ám - a munka kontextusa olyan jelentősen változott meg, mintha munkahelyváltás következett volna be.

Ilyen változásból a 10 év alatt a kollégák zöménél (11fö) egy-kettő történt: 5 kolléga esetében egy, 6-nál kettő. 1 munkatársnál három és egy esetben hat változás. Összesen 26 munkahelyváltás következett be a 13 kollégánál, így egy före átlagosan 2 munkaviszonyszintű változás jutott.

10 évvel ezelőtt 4 szakember a gyermekvédelemben, 1 a családsegítésben és 2 az idősellátásban dolgozott. Egy-egy dolgozó volt a hajléktalan-ellátásban, az ifjúságsegítésben, a foglalkoztatási ágazatban, valamint a szenvedélybeteg-segitésben és a közigazgatásban, és 1 fő hallgató volt.

7 interjúalanynak ágazati szinten változott a munkája, például az idősellátásból hajléktalanellátásba, vagy munkanélküli-segítésből gyermekvédelembe került. 3 kolléga megmaradt a korábbi ágazatán belül, ám a fenntartó megváltozott. „A szociális ellátó rendszerböl a közmüvelödés felé tolódott a munkahelyem ágazati besorolása" (Dezső, 42). A beosztásuk kisebb mértékben változott meg: addiktológiai konzultánsból országos drogprevenciós munka, ifjúságsegítés területén szakmai irányító lett, valamint családsegítősből család- és párterapeutává vált, valamint hajléktalanápolóból hajléktalanokkal foglalkozó mentálhigiénés szakember. Egy ember belépett a szakmába (hallgató volt) és egy időközben kilépett belöle: családi vállalkozásba fogott.

6 fö került vezetői vagy vezetői jellegü (szakmai vezető, részlegvezető) beosztásba. 
Döntés a váltásról: a döntés helye és háttere

Azt vizsgáltam, hogy e fontos változások tekintetében elsődlegesen kié volt a kezdeményező szerep.

1. Külső döntés következett be, amikor más (illetve nem ő) döntött:

- jogutódlás miatt változott meg a munkáltató,

- öregségi nyugdíj miatt megszünt a munkaviszony,

- lejáró pályázat miatt lett vége a munkának,

- a fenntartó változott,

- az ágazat változott meg,

- a munka karakterét jogszabályi úton alapjaiban változtatták meg,

- amikor fegyelmi úton másik munkahelyre tették a munkavállalót.

Külső döntés volt az is, amikor valakit felkértek egy munkára vagy vezetőnek nevezték ki.

2. Belső döntéshez azokat a helyzeteket soroltam, amikor a szakember maga kezdeményezett ilyen változást:

- otthagyta a volt munkahelyét,

- új munkahelyet talált,

- mellékállásban folytatja a korábbi főállású munkáját,

- külföldön kezdett élni.

A 13 interjúalany vonatkozásában 26 munkahelyváltást lehetett elkülöníteni. Ezek kezdeményezője többségében maga a szakember volt, de jelentős a munkáltató kezdeményező szerepe is (vagy az, hogy jogszabályi változás állt be) - 15 ún. saját döntésre 11 kívülről indukált jutott.

Az esetek több mint felében tehát maga a szociális munkás döntött. 7 olyan eset volt, amikor az előző munkahelyről való eljövetel szándéka volt a fő motívum ${ }^{2}$.,....nekem kell, azért szüksége van az embernek sikerélményre! És hát én azt nem találtam meg 2 év alatt. Mondjuk a családsegités az nem volt elég számomra." (Erzsébet, 44); „...a hatósági munka rész miatt, mert az nem érdekelt engem. Tehát én nem szerettem, meg nem tudtam azt eldönteni, hogy most ki kell emelni, nem kell kiemelni, védelembe vegyem, ne vegyem. Ez nekem mind ilyen lutri volt. Szóval az nem tetszett annyira, és úgy sikerült nagy nehezen. A családsegitöben volt egy hely." (Rudolf, 45)

Essék szó olyan esetekről is, amelyeket bár nem soroltak a munkahelyváltást megalapozó elsődleges indokok közé, mégis igen nyomós tényezők lehettek a munkahely megtartásának, illetve a váltásnak mérlegelésekor.

\footnotetext{
${ }^{2}$ Bár tetszetősebb munkahelyváltási motívum lehet, amikor egy valamennyire jónak ítélt munkahelyről jobbnak ítélhetőbb felé váltanak, a változásokkal majdnem fele részben elégedettség mégis rámutat, hogy az itt említett váltástípus (amikor a rossznak ítélt munkahelyröl eljövetel a cél) is egyfajta saját aktivitással kiváltott öröm, és ilyen értelemben a tanult tehetetlenség ellentéte.
} 
„Kérdező: Annak idején volt egy nehezebb családod, egy nehéz ember családfővel...

Válaszoló: Hát az egy borzasztó volt! Le is akart löni. Autóval elgázolni.

Kérdező: Tényleg? Autóval akart elgázolni?

Válaszoló: Igen-igen. Amikor a szakellátásba vitték az egyik gyereket, akkor megfenyegetett, hogy nagyon vigyázzak, mit javaslok, mert elütnek, ott a Lada. Mutatta, azzal fognak elütni majd. Úgyhogy nem volt egy kellemes figura." (Rudolf, 45)

„Emlékszem, amikor egyszer egy kapanyéllel kergettek. Berohantam a kocsiba, és magamra próbáltam rántani a kocsi ajtaját. Közben lehúztam a fejem - úgy vertek ki a cigányok a házból. Nem csukódott be, mert oda beakadt a kapanyél. Ezt azért mosolyogva, szerintem hosszú ideig nem lehet csinálni! Tehát nyomot hagy ez.” (Flóra, 45)

Említésre méltóak azok a szituációk, amikor a szociális munkásokat agresszió fenyegeti. $\mathrm{Az}$ általunk betöltött munkakörök zömében olykor előfordul fenyegetés, agresszió, tettlegesség (vagy ezek kísérlete). Az említett esetek a gyermekvédelemben történtek, de a szakmánk szinte minden szegmensében nagymértékü érték-, érdekütközések mezsgyéjén dolgozunk. Gyakran a multidimenzionális (anyagi, biztonsági, fejlödési, önérvényesítési stb.) deprivációval, frusztrációval, illetve kiszolgáltatottsággal és agresszióval átitatott, áthatott területeken, illetve emberekkel dolgozunk.

Ezek az esetek - amikor az indulatok az ügyfelek felől „felénk” irányulnak, noha nem feltétlenül „mi” vagyunk a feszültség kiváltója - további agressziót válthatnak ki bennünk is, vagy esetleges tanult tehetetlenségünk révén belső feszültséget (esetleg szorongást), amely helyzetek - a kiégés melegágyai lehetnek. Döntő hatást gyakorolhatnak - nemcsak a munkahely vagy a konkrét ágazat - a pálya, a szakma iránti elköteleződésre is, lelkileg megterhelök. Az interjúk során néhány ilyen helyzet felmerült, amikor úgy vélhetjük, hogy a munkahelyváltás vagy a pályaelhagyás mögött ez is döntő indíték lehetett.

A saját, munkavállalói döntések zöménél tapasztalható volt, megvoltak említve bizonyos külső kényszerek (vélt vagy valós pressziók, egyéb determináló tényezők), melyek kapcsán az egyén azt érzi, érezte, hogy nem volt más választása, a körülmények áldozata volt stb. Ilyen értelemben ezek is lehetnének külsőleg indított döntések, ám a körülményekre adott válasz elindításának lehetősége - még a legkonvencionálisabb helyzetekben is - mégis a cselekvőre mutatott.

\section{$\underline{\text { A váltások értékelése }}$}

15 esetben döntött maga a szakember a váltásról. E váltásokat 6/4 arányban értékelték pozitívnak, illetve negatívnak. (A döntés helye és az [elsödleges, kiemelt] értékelés között nincs feltétlen ok-okozati összefüggés.)

A 11 esetben, amikor külső ok miatt következett be a váltás, csupán 4 esetben döntött a munkáltató, 7 esetben ez indirekt módon következett be, nem egy az adott munkavállalóra irányuló döntés következményeként. A külső ok miatti változásokat a szociális munkások 3/8 arányban értékelték jónak vagy rossznak. A 8, negatívnak értékelt külső változás során 4 esetben a munkakör megmaradt, csak a fenntartó más lett (3 eset), egyszer a munkastruktúra alapvetően változott meg. Két esetben szünt meg a munkahely, két esetben pedig fegyelmi büntetés előzte meg a váltást. 
Szót kell ejteni azokról a munkahelyváltozásokról, amelyek pozitívan, jutalmazóként lettek értékelve, ezért ellenpontjai lehetnek a korábban említett, mintegy kényszer motiválta váltásoknak. Ezek között megtalálhatók belsőleg motivált „, az tart csak a pályán - mert ugye nyugdij mellett dolgozom -, hogy én nagyon megszerettem a család-és párterápiát" (Gyula, 64), és a külső lehetőségként bekövetkező változások is: „Felhívott a Tibi, hogy ő hallotta, hogy én nagyon jó szociális szakember vagyok, ö meg keres valakit, és hogy eljönnék-e." (Zita, 37)

Az értékeléseket a változásról szóló beszámolók narratívái erősítették meg, egészítették ki, árnyalták. Előfordult, hogy a direkt értékelés elmaradt, ám a releváns szöveg egyértelmü értékelő mozzanatot tartalmazott. Nem ritkán a válaszadó úgy érzi, hogy a váltás összességében jó volt, mégis: az akkor megtörtént váltás - vagy annak körülményei - lehetett rossz, esetleg emlékezetesen fájdalmas.

Más változások a munkával összefüggésben

Eddig zömében a munkahelyváltásokat vettük számba, most azokat a - munkahelyváltásnál kisebb - változásokat nézzük meg, melyekről a válaszadók beszámoltak a munkájuk kapcsán.

23 lényegesebb változást említettek. A megfogalmazások többségében tetten érhető a múlthoz való viszonyítás. Többnyire a külső körülmények objektív megváltozásáról számoltak be, néhány esetben azonban csak az interjúalany számára (életében) jelentett változást: meglehet, hogy az értékelt munkahely esetleg mindig is ilyen volt, de az ő számára ez egy említésre méltó fejlemény. Például: kötetlen, rugalmas; megbecsülnek; lehetöség van szakmai fejlödésre. E változások pozitív vagy negatív értékelése az interjúk szövegfolyamában, implicit módon is megvalósult.

Pozitív állítások, gyakoriság szerint:

új kihívások értek (8); vezetö vagy szakmai vezetöi feladatot kaptam (7); változatos lett a munkám (7); kötetlen, rugalmas (6); megbecsülnek (5); lehetöség van szakmai fejlödésre (5); növekedett a munka eredményessége (4); megtalálnak a munkák (3); az intézményi légkör jobb lett (2); nyilt a kommunikáció (1); rend van (1).

Negatív állítások, gyakoriság szerint:

kevesebb idöm maradt ügyfelezni (6); változott a fenntartó vagy a szakmai irányitás (5); az intézményi légkör rosszabb lett (3); a bérem csökkent (3); növekedett az adminisztráció (3); több lett a munkám (3); eszköztelenség (3); kevés lehetöség a segitésre; csökkent a munka eredményessége (2); hatósági jellegü munka lett (2), stresszes (1); fluktuáció (1); kevésbé hozzáértö kollégáim lettek.

A 23 féle változást nagyjából fele-fele arányban értékelték pozitív és negatív típusúként (11/12). 49 pozitívan értékelt változásra 33 negatívan értékelt változás jutott. Érdemes említést tenni azokról, akik ezen aránypár tekintetében szélső értékeket mutattak. Volt, akik egyenlege erősen pozitív volt. Ilyen volt Flóra (7/0), aki a pályaelhagyás után 10 évvel nyilatkozott. Hogy foglalkoztatja-e a volt munkája? - „Engem nem, még álmomban sem.” Zita (7/1) úgy érzi, nagyon jó munkahelyet talált: „, Ez egy nagyon-nagyon nagy fölüdülést jelentett." 
Akadtak, akik a változások összességében szomorúbbak voltak. Erzsébet (0/5) éppen jobb munkahely reményében változtat. Márk (1/4) a munkájában elkötelezett, de nehézségek terhelik: ,20\%-kal kevesebb fizetésem van, mint egy közalkalmazottnak, de 20\%-kal többet dolgozom munkaidön kivül [...] 5 éve beragadtam bérileg. Ami miatt úgy érzem, mintha nem volna elég jó a munkám.” Rudolfot (1/5) a munkahelyi változások rosszul érintették: „egyre kevesebb lehetösége volt a családsegitönek, egyre kevesebb dologba tudtunk beavatkozni. Semmit sem tudtunk már adni gyakorlatilag a végén [...], hogy mi mennyit tudunk segiteni, hát azt már senki nem nézi meg. Tényleg nem is sokat tudunk."

\section{Egyéb kiegészítő, munkajellegü tevékenységek változásai}

Azokat az elmúlt 10 év alatt kezdett tevékenységeket soroltam ide, amelyeket a válaszadó a fóállásától függetlenül végez, de szociális munkás minőségében. Ezek a következők:

- önkéntes munkába kezdett;

- szakmai érdekképviseleti csúcsszervezetben elnökségi tagként tevékenykedik;

- alapítvány létrehozásában segített;

- óraadó volt felsőoktatási intézményben;

- korábbi munkahely keretén belül több, jól körülírható munkát végzett el (egymást követő, határozott idejü munkák);

- mesterképzésbe kezdett;

- elvégzett egy coach-képzést: csoportfacilitátor és teamcoach lett.

Ilyeneket 3 válaszadó említett. A tevékenységek kiegészítik a válaszadó tevékenységeit: a személyiségük, fő munkatevékenységük az elsődleges munka által le nem fedett részét, energiáit, tehetségét stb. aknázzák ki, a szakember életminőségére jelentékeny hatást gyakorolhatnak. Az emberben meglévő fejlödési szükségletre reflektálnak, egyfajta önmegvalósításként funkcionálnak: hasznos és pozitív hatásúak.

Személyes változások

„Miben változtál a 10 év alatt?”

Kíváncsi voltam, hogy az interjúalanyok egy évtized alatt milyen „belső” változásokon mentek keresztül, neveznek meg a munkával összefüggésben. Amelyekröl úgy gondolják, hogy hatással vannak, lehetnek a munkájukra, a szakmai személyiségükre.

48 olyan változást említettek, amelyet intraperszonálisnak, intrapszichésnek nevezhetünk. Ez 26-féle változás, ismétlődésekkel. 21 változás pozitívan, fejlődésként lett említve, 4 megfogalmazás negatív tendenciát ír le, és 1 állításról ez önmagában nem eldönthetö ( $a$ szociális munkás identitása gyengült [2 emlités] másik identitáskomponens ezzel együtt erösödött).

A belső változások két fö típusát tudtam megkülönböztetni: egyfelől a tartós személyiségváltozásnak ( fejlődés) tünő változásokat, tulajdonságokat, vonásokat, másrészt a kevésbé tartósnak tünő, valamilyen tárgyra irányuló attitüdök módosulását. 
A személyiség(vonás)-szintü változásokhoz (9-féle) az alábbiakat soroltam: reálisabb lett, nem idealista (3 emlités); érettebb, kiforrottabb lett (4); árnyaltabbá vált (1); teherbíróbb lett (2); már határozottabb (1); fontosabb lett saját maga számára (2); kiteljesedett, jobban érzi magát (2); nyugodtabb lett (1); visszább vesz a saját elvárásaiból (1).

Az attitüdváltozásokat (17-féle) 3 alcsoportba osztottam: kognitív (7), érzelmi (8) és viselkedéses $(2){ }^{3}$

A kognitív változások körébe az alábbiakat soroltam: tapasztaltabb (3 emlités); jobban látja a kereteket, határokat (3); már nem akar mindent kontrollálni (2); belátta, hogy nem kell mindig jól éreznie magát (1); integrált több szoc. munkás stílust (1); szociális munkás identitása gyengült (2); szociális munkás identitása erösödött (3).

Az érzelmi változások közé ezek kerültek: kisebb dolgoknak, kisebb eredményeknek is örül (2 emlités); belefér, hogy nem tökéletes; nem kell mindent tudnia (2); óvatosabb, bizalmatlanabb egyes kliensekkel (1); csökkent a pálya iránti motivációja (1); elbizonytalanodott szakmailag (1); kiégettnek érzi magát (1); nem kell mindenkinek mindenáron megfelelnie a szakmában (1); úgy érzi, sok méltánytalanság érte (1).

Az alábbi, viselkedéses változásokat különböztettem meg: gyakrabban konfrontálódik, jobban kiáll magáért, küzd (4 emlités); képessé vált, hogy a dolgokat eltávolítsa magától, ne vigye haza (2).

A változások jelentékeny része (12 említés) egy válaszadótól (Zita, 37) származik, akit a jelenlegi munkahelye sok pozitív feltétellel, élménnyel gazdagított. A pozitív „egyenlege” miatt - nem meglepő módon - közlékenyebb lehetett, ellentétben azzal, aki a közelmúltban több negatív érzést, ambivalenciát megélt a munkával kapcsolatban.

Egy interjúalany - a fenti, standard kérdésre - magával kapcsolatban több változást is említett, melyek azonban nem intrapszichés változások, hanem külső, interperszonális cselekvések, történések (,Kaptam külső szakmai elismeréseket a klienseimtöl és a munkatársaimtól: országosan ismert szakember lettem a szakterületemen”) és elvégzett tevékenységek voltak (,,szakmai képzéseken vettem részt. Végig tudtam vinni szakmai folyamatokat") (Dezsö, 42).

Közvetett változások

„Hogyan látod, miben változott a szakma az évek alatt?”

Arra voltam kíváncsi, hogy a szociális munkás a munkája kapcsán közvetlenül megélt, érzékelt változásokon túl - ám még mindig a munkával összefüggésben - milyen közvetett változásokat érzékelt. A kérdésben elfogadtam, amit az egyes válaszadó e kérdésre válaszolt, illetve amit más helyütt a beszélgetés során a „szakma”, „szakmai”, „szociális szféra” kifejezések alatt ő értett, ezekkel kapcsolatban közölt.

\footnotetext{
${ }^{3}$ A fenti besorolás kissé önkényes - lehet, hiszen nehéz ezeket a folyó szövegben előforduló változásokat kiragadni és világosan különválasztani, minden kétséget kizáróan besorolni -, inkább a mintán belüli tendenciák felvázolásában lehet segítségünkre.
} 
9 válaszadó 29 olyan változásról számolt be, amely a szakmát érintette, és túlmutatott az általa végzett munkán, munkakörön.

A felsorolt változások közül 3 (az összes említés tizedét sem elérő arányban) pozitív tendenciát fogalmaz meg (többen lettünk; a társadalom fejlödése révén a segitség a kultúránk részévé válik: „látható már egy fejlödés, és minél inkább eljut a mi társadalmunk is egyre magasabb fejlettségi szintre, annál inkább a kultúránk része lesz az, hogy másokat segitsünk" [Zita, 37]), a maradék 26 a tágabb kontextus rosszabbodását írja le.

\section{A változások színtere}

E változások helyét 2 jellemzőbb - szimbolikus - színtérre láttam besorolhatónak: amelyek a szakma szintjén (primer módon) valósultak meg (a válaszok fele részében), valamint azok, amelyek a társadalomban mentek végbe (harmaduk), és ennek révén gyakoroltak hatást a szociális szakmára (másodlagos, közvetett változás). 5 esetben beszélhetünk politikai, szakmapolitikai, és 2 esetben képzési színtérről, melyek - jellegüknél fogva - elsődleges, közvetlen szakmai változásokként értelmezhetők.

$\underline{\text { A válaszadók által leírt társadalmi változások összefoglalása }}$

Növekedett a szegénységben, mélyszegénységben élök aránya. Növekszik a szakadék közöttük és a tehetősebbek között, valamint polarizáltabb lett a társadalom. A középosztály eltünőben van. Ezek a tendenciák egyre nagyobb munkaterhet rónak a szociális szakmára. Az emberek többsége a megoldások keresésével van elfoglalva, ezért nem ismerték meg, illetve nem tudják megbecsülni a szakmát, melynek csökkent a társadalmi státusza.

A szakmai változásokat közvetlenül leíró folyamatok összegzése

A szférában a bérek alacsonyak, romlottak (nem emelkednek, illetve a stagnálás miatt folyamatosan csökken a vásárlóértékük), ami miatt elöfordul, hogy egyes betanított munkások többet keresnek, mint a szakmában dolgozók. A kollégák egy része az egészségügybe, illetve a közoktatásba ment át a jobb bérek miatt. A pályán csak az igazán elkötelezettek maradtak, illetve sok új (gyakorlattal, szakirányú gyakorlattal nem rendelkező) munkaerő áramlott be, ami miatt a szakma felhígult, ellaposodott. Több lett a szociális szférában dolgozók, ezen belül a szociális munkások száma is.

Megszüntek, illetve megszüntettek korábban létrejött, létrehozott drogszakmai szervezeteket. Akad, aki szerint a szociális szféra a pénzről szól. A szakma minden tekintetben lejjebb csúszott. Összegezve: az a baj, hogy nehéz a munka, a munkához (és a megélhetéshez képest is) kevés a fizetés, nincs ismertségünk, nincs elismertségünk.

A változások közvetlen oka

A felsorolt változások jellege túlnyomórészt (23 említés) olyan volt, melyek kvázi maguktól, indirekten jöttek létre, amennyiben azok konkrét bekövetkezése nem szándékolt, nem egy konkrét beavatkozás következtében jöttek létre. 6 olyan változást említettek, amely direkt törekvést fejez ki vagy feltételez. 
A változás lehetöségei (határhelyzetek a munkában)

„,Minek kellene ahhoz történnie, hogy azt mondd, hogy köszönöm, ennyi volt.”

Kíváncsi voltam, mennyire erős a kapocs, az elköteleződés a szakember, a munkája, illetve a szakmája között, pontosabban: mit gondol erröl a kérdésröl. Melyek azok a tényezök, amelyeket még elfogadhatónak, tolerálhatónak tartanak, és melyek, amelyeket már nem. Hogy érzik és értékelik, a jelenlegi munkahelyük, munkájuk mennyire teszi próbára a türőképességüket, mennyire közelíti annak határát. Az elméleti válaszok mellett (melyek arra vonatkoznak, hogy milyen esetben váltana munkát) több gyakorlati válasz is érkezett: vagy több ilyen váltáson is rég túl volt már, vagy egy ilyen váltás mérlegelési folyamatának közepén van, de akadt olyan is, aki a döntést már meghozta, és a változtatási folyamat közepén találkoztunk.

Vegyük sorra a válaszokat.

1 válaszadó tekintetében inadekvát a kérdés, hiszen sok évvel ezelőtt otthagyta a szociális szférát. 1 szakember nem tud olyan helyzetet elképzelni, ami miatt otthagyná az állását (különös tekintettel a nyugdíjig hátralévő, legfeljebb 2-3 évre). 1 interjúalany életében ilyen döntési helyzetek folyamatosan voltak és vannak. Nem derült ki, milyen feltételek esetén utasít el egy állást (vagy megbízást) - illetve egyezik bele. Emiatt az sem tudható, hogy ezeket a döntéseket inkább külső feltételek, körülmények vagy belső, személyes okok miatt szokta meghozni.

10 szakember a munkahelyváltásnak 15 lehetséges (vagy fennálló) okát említette.

$\underline{5}$ esetben külső ok miatt hagynák ott a munkahelyet:

- a rendszer müködésének drasztikus vagy tartós romlása

○ „valami óriási csalódás magában a rendszerben. Rendszerszinten valami iszonyatos nagy, megdöbbentö, meglepö valami. Ha vállalhatatlannak találnám [...] Hogyha azt látom, hogy maga a rendszer - a hajléktalanokra visszatérve kicsit - hatósági eszközzé válik. Voltak ilyen kezdeményezések, hogy az utcáról bevigye öket - akár - a rendörség. [...] Hogyha a szakma elmenne egy ilyen irányba, nekem az komoly fejfájást okozna." (Márk, 39)

- „1 éve van ez a müködtetési forma. És én egy-másfél évet adtam arra, hogy ezt kipróbálom, hogy tudok-e ebben együttmüködni, meg dolgozni. Hogyha ezen belül nem áll be az, hogy lássam azt, hogy miért." (Dezső, 42)

- ügyfél tettlegessége

„Itt egyszer-kétszer kerültem olyan helyzetbe, hogy nagyon necces volt. Pszichiátriai kliens is volt, borzasztó rossz állapotban, a pszichózisának olyan részében [...] Az egy nagyon ijesztö helyzet volt. Szenvedélybeteg kliensnél is volt olyan, amikor tényleg hajszálon múlt, hogy ebböl nem lesz ebböl bántás [...] Beugrott nekem a másik kliens mellé, de volt, hogy rám rúgta az irodaajtómat, elém ugrott az utcán. Szóval ebben minden benne volt, és ebben a folyamatos készültségben lenni, hogy mikor, melyik bokorból ugrik ki elém azzal, hogy most, azonnal, az egy nagyon frusztráló helyzet" (Zita, 37) 
- adminisztráció fokozódása

„olyan adminisztrációs követelmények lépnek életbe, hogy az ember nem gyözi kapkodni a fejét. Bemegyek a céghez, és csinálok 2 terápiát (ami 3-4 óra), és majdnem 5 óra eltelik, mire kijövök, mert nekem be kell vezetni a forgalmi naplóba, aztán van nekem egy füzetem, amibe be kell írni minden családtagnak az adatait, és ahányan vannak, annyiszor" (Gyula, 64)

- globális elégedetlenség a munkahellyel.

4-szer belső okot neveztek meg:

- saját szakmai müködés elégtelensége (2)

○ „Hogyha a munkámat nem tudnám maximálisan megcsinálni, és akkor emiatt többször számon lennék kérve, hibákat követnék el." (Rebeka, 30)

○ , Valami nagy hibát elkövetek, vagy valami durva eset, amit nem tudok kezelni." (Rudolf, 45)

- kiégés (2)

„,Vagy ha kiégnék. Ha a munkámat már nem tudnám, és több kárt csinálnék, mint hasznot. Meg családokat hagynám cserben, meg ilyenek, akkor azt mondanám, lehet, hogy igen." (Rebeka, 30)

$\underline{6}$ esetben olyan okot neveztek meg, amely a szakember és a munkahely közötti viszonyrendszer - megromlására - vonatkozik

- ha bántanák szavakkal, iránta való viselkedéssel \{3\}

○ „Ha piszkálnának. Az, hogyha elmondják, hogy miben hibáztam, azzal nincs gond. Abszolút nem, majd legközelebb megpróbálom." (Júlia, 43)

○ „...volt néhányszor már! Ha emberileg kapnék olyan pofont.” (Emma, 47)

- „...hogyha ugyanaz lenne, mint az elözö munkahelyemen. Ha gyomorgörccsel mennék dolgozni. [...] Én szeretem ám az állandóságot. Ha engem nem bántottak volna a hajléktalanszállón, én örök életemben, plusz még két napot maradtam volna." (Katalin, 46)

- ha nem müködne a kapcsolat a munkahellyel $\{2\}$

○ „Még 2 hét van, amíg tarthat ez a nehéz helyzet az elvileg már nyugdíjba vonult elödömmel. Teljesen jól elvagyok, mert tudom, hogy az a határom, amit én most kiszabtam magamnak. Egy, vagy két este nagyon rosszul éreztem magam, mert éreztem, hogy ez most így nem fog menni." (Júlia, 43)

- „...nem látom azt, hogy beállna egy stabilitás abban, hogy hogyan dolgozunk. Aminek van rendszere, és érthetö, kiszámitható. Ha ez nem lesz meg, akkor el tudom képzelni, hogy váltok." (Dezső, 42)

- ha nem becsülnék meg anyagilag

„...hogyha tovább szorul az én munkaköröm afelé, hogy csak szakmailag irányitsak, de ezért mondjuk nem kapok vezetöi pótlékot, vagy ilyesmi, akkor én el tudom képzelni, hogy váltok." (Dezsö, 42) 
10 szakember a munkahelyváltásnak 15 - lehetséges vagy fennálló - okát említette. 5 esetben külső ok miatt hagynák ott a munkahelyet, 4-szer belső (saját szakmai személyiséget negatívan érintö) okot neveztek meg. 6 esetben olyan okot fogalmaztak meg, amely a szakember és a munkahely közötti viszonyrendszer - megromlására - vonatkozik. A mintázatban a 3 föbb csoportba sorolható felmondási okok (belső - személyes, külső környezeti, valamint a viszonyszerü - kapcsolati) hasonló arányban fordulnak elö.

Van, amikor a munkahelyi rendszer hosszabb távú vállalhatatlansága merül fel, ahol kihat a munkahellyel való kapcsolatra, és akad, aki számára a rossznak ítélhető müködés erkölcsi szempontból vállalhatatlan. Négyen a saját, esetlegesen elégtelen müködésüket tartanák elviselhetetlennek, és - ezen belül - ketten e müködésállapot szélső helyzetét említették, mely a kiégést jellemzi (többek között).

4-en fogalmaztak a „bántás” kifejezéssel (tettleg, 3 esetben verbálisan), ahol velük már megtörtént esetekre utalnak vissza. Ilyen értelemben ezek nem elképzelt kockázatok, hanem reálisak (korábban megvalósultak).

A „csalódás” kifejezésről több helyen felmerült, ami tulajdonképpen a feltett kérdést fogalmilag süríti (mi lenne számodra a csalódás?), és minden válasz lényegileg erre felel meg, amennyiben a munkahelyváltást indukáló jelentőségü csalódásról beszélünk. A csalódás fogalom itt megkerülhetetlen: megfogalmazható egy szük értelemben vett érzésben: nem azt kaptam, amit vártam (frusztráció), de racionális megállapításként is (én nem erre szerződtem $)^{4}$. Megfogalmaztak olyan helyzeteket, amikor korábban már csalódtak ekkorát, olyat is, amikor a jelenben élték meg ezt, és határidőt tüztek ki, valamint olyat is, amikor már a jelenben megszületett a döntés a váltásról.

Utoljára említem azokat a megfogalmazott helyzeteket (4 említés), melyek eddig még nem történtek meg, fiktívek, így nehéz megbecsülni, megjósolni a döntéshez vezető konkrét körülményeket, azok szubjektív súlyosságát.

\section{Észlelt munkaeröpiaci lehetöségek}

„Ha úgy adódna, tudnál máshol dolgozni?”

Az érdekelt, hogy a válaszadók (szerint) - adott esetben - könnyen találnának-e munkát, azaz milyennek tartják szociális munkásként a munkaerőpiaci (mobilitási) lehetőségeiket. Ennek a helyzetnek az értékelésére, szubjektív érzékelésére voltam kíváncsi. ${ }^{5}$

A 13 válaszadóból 11 élethelyzetét tekintve volt a kérdés adekvát. 1 fő már nyugdíj mellett dolgozik, további egy fő pedig már nem szociális munkásként. 1 kolléga találta úgy, hogy a kora miatt nem könnyen találna munkát. Az interjúalanyok zöme úgy válaszolt, hogy

\footnotetext{
${ }^{4}$ Kádár Sári javaslata minden szociális munkás számára, önmagának: „»Ezt akartam, tudom-e tartósan vállalni ezt a hivatást?« Ezt a nem könnyü, de időben felteendő kérdést kell őszintén, becsületesen megválaszolnia. Szomorú és veszélyes, ha valaki állandó szorongással, reménytelenül, vagy fásultan végzi ezt a munkát." (Kádár 1994: 117) A csalódás megfogalmazása nehéz, de segítségünkre lehet.

${ }^{5}$ Véleményem szerint nem mindegy, hogy valaki úgy néz szembe a munkából adódó nehézségekkel, hogy egyébként tudna máshol is dolgozni, vagy úgy, hogy a jelenlegi munkája számára egyfajta egzisztenciális kényszer is.
} 
találna munkát. Legtöbbjük általánosságban, nem leszükítve konkrét munkára, munkahelyre. Néhányan a szociális szférát nevesítették lehetőségként, mások a közigazgatást, egy fö a tréningezésben látná az alternatívát. Ketten kihangsúlyozták, hogy akár fizikai munkát is vállalnának.

A szakemberek véleménye, képe a saját kompetenciáikról a munkakeresés (és annak megtartása) vonatkozásában

Nyolcan a saját oldaluk megvilágításával (is) válaszoltak a kérdésre, saját magukat munkaeröpiaci szempontúan értékelték. 2 válaszoló hangsúlyozta, hogy egy ilyen helyzet neki nem okozna nagyobb nehézséget. Ketten magabiztosan, a kedvező kimenetel erős tudatában mennének bele ilyen helyzetbe, egy fő pozitívan megélhetö kihívásként.

A szociális szakmában munkaerőhiány lehet, amelyet a résztvevők evidenciaként érzékelnek, és emiatt a kínálati oldal hangsúlyozódott ki jobban: számukra nem az ún. objektív munkaerőpiaci lehetőségek megléte a kérdés, hanem hogy a személyes és szakmai kvalitások, illetve az észlelt, megélt önértékek, az ilyen szituációkban jól mobilizálhatóak-e.

\section{Az eredmények összegzése}

\section{Munkahelyváltás}

26 munkahelyváltás következett be a 13 kollégánál, melyek többségében maguk döntöttek. Szomorú, hogy a saját döntések zömét munkahelyi presszióval vagy más külső kényszerrel indokolták, illetve hogy ezen váltások majdnem felében az előző munkahelyről való eljövetel szándéka volt a fó motívum. 11 esetben a váltásra külső ok miatt került sor: a munkáltató döntött vagy indirekt módon következett be. Az interjúalanyok többségének ágazati szinten változott a munkája, 6 fö került vezetői vagy vezetői jellegü beosztásba.

Amikor a szakemberek maguk döntöttek a váltásról (15 eset), azokat nagy arányban értékelték pozitívnak, amikor külső hatás eredményezte a váltást, csupán harmadában.

A szociális munkások ügyfeleinek jelentős része multidimenzionális deprivációban létezik, gyakoribb a frusztráció tartós élménye. A kliensek életét átható, valamint a felőlük felénk irányuló agresszió bennünk is frusztrációt, agressziót válthatnak ki. Ez vagy manifesztálódik a szakember kapcsolataiban, vagy belső feszültséget, szorongást vált ki: mindkét eset a kiégés magasabb kockázatát hordozza. A szakember saját döntése munkahelyváltás tekintetében is - saját aktivitással kiváltott öröm, mely fontos képesség lehet a megelégedettség felé törekvésben, a kiégés megelőzésében.

Kisebb változások a munkával összefüggésben

A kollégák 23-féle lényegesebb munkahelyi változást említettek, összesen 82-szer. Többnyire a külső körülmények objektív megváltozásáról számoltak be, néhány eset csupán az interjúalany számára jelentett változást. A pozitívan és negatívan értékelt változások összességében 6/4 arányban jelentek meg.

\section{Kiegészítő tevékenységek változásai}

3 válaszadó számolt be 8 olyan tevékenységről, amelyek kiegészítik a fö tevékenységüket. Ezek a szakemberek életminőségére pozitív hatást gyakorolva egyfajta önmegvalósításként funkcionálnak. 
$\underline{\text { Személyes változások }}$

$\mathrm{Az}$ interjúalanyok 48 intraperszonális-intrapszichés változást fogalmaztak meg. 31 alkalommal attitüdváltozást (kognitív, érzelmi és viselkedéses), 17 esetben tartós személyiségvonás-változást (fejlődést) említettek. A megemlített változások többsége (21) pozitívan, fejlődésként lett említve, 4 negatív tendenciát ír le. A megfogalmazások nagy többségében tehát fejlődésként értékelt belső változásokat fogalmaz meg.

Az interjúalanyok többségénél relatív megelégedettséget tapasztaltam, függetlenül a nagyon aktuális helyzetüktől, és az inkább az azokra adott válaszképességben gyökereznek: hogy a kapott lehetőségekkel, helyzetekkel mihez tudnak kezdeni. Általában egyaránt tudják integrálni a jó, a nehéz és a kényszerü tapasztalatokat is.

$\underline{\text { Tapasztalatok, benyomások a szakmai, valamint a szakmát érintő változásokról }}$

A megemlített változások 2 fő színtere az elsődleges, „szakmai”, a másodlagos „társadalmi”, melyek a társadalom révén közvetetten gyakoroltak hatást a szociális szakmára. 5 esetben beszélhetünk „,politikai”, „,szakmapolitikai”, és 2 esetben „képzési” színtérről. Az interjúalanyok tizedében pozitív tendenciát fogalmaztak meg, a tapasztalt változások zöme a tágabb kontextus rosszabbodását írja le.

Társadalmi típusú változások: növekedett a (mély)szegénységben élök aránya, a szakadék (olló) közöttük és a tehetösebbek között, valamint polarizáltabb lett a társadalom. A középosztály eltünöben van. Ezek a tendenciák egyre nagyobb munkaterhet rónak a szociális szakmára. Az emberek többsége nem ismerte meg, illetve nem tudják megbecsülni a szakmát, melynek csökkent a társadalmi státusza. Szakmai típusú változások: a szociális szférában a bérek alacsonyak, csökken a vásárlóértékük. A kollégák egy része az egészségügybe, közoktatásba ment át, korábbról csak az elkötelezettek maradtak. Sok, gyakorlattal nem rendelkezö munkaerö áramlott be - ezért a szakma felhígult. Megszüntek, illetve megszüntettek korábban létrejött, létrehozott drogszakmai szervezeteket. Akad, aki szerint a szociális szféra a pénzröl szól. Dominánsan fogalmazódtak meg az alábbiak: Nehéz a munka. A munkához és a megélhetéshez képest is kevés a fizetés, nincs ismertségünk, nincs elismertségünk.

A felsorolt változások túlnyomórészt indirekten jöttek létre, amennyiben azok bekövetkezése nem szándékolt vagy nem egy konkrét beavatkozás következtében alakult ki. Ötödében olyan változást említettek, amely direkt törekvést fejez ki, vagy leginkább azt feltételez.

A változás lehetőségei (határhelyzetek a munkában)

10 szakember a munkahelyváltásnak 15 lehetséges okát említette. 5 esetben külső ok ( $p l$. ügyfél agressziója) miatt hagynák ott a munkahelyet, 4-szer a saját szakmai személyiség rossz müködésére ( $p l$. kiégés) vonatkozó változást neveztek meg okként és 6 esetben olyat, amely a szakember és a munkahely közötti viszonyrendszer - megromlására - vonatkozik. Van, amikor a munkahelyi rendszer hosszabb távú vállalhatatlansága merül fel.

\section{Észlelt munkaerőpiaci lehetőségek}

10-en egyöntetủen úgy válaszoltak, hogy találnának munkát. 2-en a szociális szférát, 2-en a közigazgatást nevesítették, egy fö a tréningezésben látná az alternatívát. 2-en - adott esetben nem feltétlenül diplomás, akár fizikai munkát is vállalnának.

8-an a saját oldaluk megvilágításával (is) válaszoltak a kérdésre: mindannyian a kedvező 
kimenetel erős tudatában mennének bele ilyen helyzetbe. A résztvevők számára tehát nem az objektív munkaerőpiaci lehetőségek megléte a kérdés, hanem hogy a személyes és szakmai kvalitások, illetve az észlelt, megélt önértékek, amelyekről úgy érzik: az ilyen szituációkban jól tudnak mobilizálni.

\section{Diagnózisok és lehetséges változások a szociális munkában}

Az interjúalanyok számos tágabb kontextusú problémát, hiányosságot említettek. Ezek gyakran az ismertséggel, az elismertséggel, presztízzsel kapcsolatosak, illetve összefüggenek vele. Ezeket több szerző is megfogalmazta korábban, ezért érdemes őket is felidézni.

A képzésben megmutatkozó sokszínű szakmakép hamar széttöredezett lesz, csupán egy sztereotip segítő szakmakép marad meg. Ahogy Szoboszlai Katalin megfogalmazza: „,Végletekig leegyszerüsitett a szakmai önkép. A szociális munkás ezek alapján hallgató a képzésben, aztán családgondozó, utcai szociális munkás, közösségi koordinátor" (Szoboszlai 2014: 89).

Az észlelt problémákhoz és a jövőben lehetséges bármely változáshoz idekívánkoznak Kozma Judit gondolatai: ,elég csekélynek tünik jelenleg az érdekérvényesitési esélyünk [...] mi a hátrányos helyzetüekért, a »politikai némákért « viselünk felelösséget” (Kozma 1996: 112).

Fónai-Kiss-Fábián 1999-es kutatási beszámolójukban megszerzett adatokból hasonló vélekedéseket mutattak ki: „Az alacsonyabb társadalmi presztízs általában alacsonyabb érdekérvényesitési képességgel és hatalommal jár együtt, így a hallgatók rangsora szerint a szociális munka társadalmi presztizse és érdekérvényesitö képessége, valamint hatalma alacsony." (Fónai, Kiss, Fábián 1999: 129)

Győri Péter az elismertség, a szakma észlelt gyengeségének hiányát további konkrét szemponttal érzékelteti, érteti meg: ,szociális szakmában dolgozók döntő többsége beosztott munkavállaló, annak minden helyi nyügével és terhével. Még saját munkavállalói érdekeinek védelméhez sem rendelkezik elegendö municióval. Többségük egzisztenciális nyomorúságát csak tetézi munkájuk fontossága elismerésének a hiánya." (Győri 2014: 77)

Másutt a hallgatók kérdezték a kívülállókat, melynek nem túl biztató tapasztalataira, tendenciáira világít rá Szoboszlai Katalin: „A rendszerváltás idején a szocialista munkással azonositották a szociális munkást, jelen idöben a közmunkás, a közhasznú munkás, a köztisztasági vállalatnál dolgozók jutnak eszébe a válaszadóknak." Írásában széleskörüen fogalmazza meg a megtenni érdemes lépéseket. Többek között: „A szociális munka és a szociális munkás helyén kezelése létfontosságú. Kiállással, bemutatással, önkifejezéssel láthatóvá kell tenni a munkánkat. Kommunikációnknak minden társadalmi réteghez szólnia kell, felhiva a figyelmet azokra az egyénekre, csoportokra, közösségekre, akikhez a szociális munka elér, akiknek segitséget nyújt. Szakmai és közéleti publicitást segitö felületekre és szakcikkírókra, újságírókra is szükségünk van, mivel ök azok, akiknek szakma-és közvélemény-befolyásoló szerepük van." (Szoboszlai 2014: 93)

A megbecsültségről Szabó Lajos ekképp ír: „furcsa ellentmondás, hogy miközben a társadalom nagyra értékeli az elesettek segitésében karitatív eröfeszitéseket tevök munkáját, a 
segítö munka legnehezebb területein dolgozó szociális munkások a társadalmi megbecsülés, presztízs szempontjából meglehetösen alacsony pozícióba szorulnak” (http 4).

\section{Az eredmények gyakorlati felhasználásának lehetőségeiről}

Az eredmények a szociális munkásoknak, a szakmának, valamint a szakmára készülőknek adhatnak bepillantást - egyfajta pályatükörként - abba, hogy milyen változásokon mennek, mehetnek keresztül a kollégák 10 év alatt. Rávilágítanak, hogy mindezt milyen érzés, élmény megélni, sőt felvillantják az emberi változások hosszú távú értékelésének azon jellegzetességét, hogy amit a múltban még negatív (és sokszor fájdalmas) változásként éltek meg, az mára tágabb perspektívában már tünhet jó és hasznos változásnak, vagy akár fordítva. A szakmáról információt szerezni akaró laikusok számára is kézzelfoghatóan hozhatja közelbe a szociális munkások közvetlen életét.

Az eredmények a képzésben részt vevő hallgatók számára az elméleti megközelítésü tananyagok mellé kiegészítésül szolgálhatnak, a hazai szociális munka, szociális munkások helyzetét bemutatandó. Modellezheti számukra, hogy milyen változások lehetségesek egy szakember életében, és akár egy-egy munkahely, munkakör szintjén. Milyen szakmai sorsok, pályacsomópontok tárulnak az olvasó elé a közlésekből. Milyen utak, szakmai-mobilitási lehetőségei lehetnek és választásai vannak, és milyen válaszokat adhat, lépéseket tehet erre a szakember, és ezek hogyan müködnek a gyakorlatban.

A szakmát közvetetten érintő változások számba vétele rámutat, hogy nincsen ismertségünk, elismertségünk mint szociális munkások. Ha a mi-tudatunk fejlődhetne, erősödhetne, és mindannyian - nem csupán a szakmának egy szük, nem reprezentatív szegmense megtalálnánk azokat a fórumokat, találkozási pontokat (virtuális vagy valós találkozásokat), akkor ezekre a problémákra megpróbálhatnánk közös válaszokat kidolgozni vagy közösen tovább elemezni a szakmát, és annak megoldásra váró problémáit, helyzeteit. A szakmában dolgozókat - bár folyamatos személyes tapasztalattal rendelkeznek a gyakorlatban folyó szociális munkáról, a tekintetben orientálhatják, hogy képesek legyenek azonosítani azokat a külső tényezőket és belső élményeket, érzéseket, amelyek a változás feltétlen velejárói, és azokat, amelyek teljesen egyediek és esetlegesek lehetnek. A más településen, ágazatban vagy szektorban dolgozó kollégákkal kapcsolatban egy többlettudásra tehetnek szert, ami a saját munkájuk, tapasztalatuk kapcsán csökkentheti az esetleges, de oly sok helyütt (föleg kisebb településeken) tapasztalható elszigeteltséget, szakmai magára hagyatottság érzést. Ez a folyamat a szakma saját önismeretét, önbecsülését, szakmai identitását erősítheti, melyek a stabil kollektív identitás, mi-tudat kialakulásának nélkülözhetetlennek tủnő mérföldkövei.

A szakmai irányítók a kapott eredményeket a szociális munka müködtetése során használhatják fel, mint a szociális munkás munkavállalók emberierőforrás-gazdálkodói. A monotóniára, konfliktusokra, érzelmi-pszichés terhelésre, elfáradásra vonatkozó tapasztalatok és az ezek változásait végigkövető évtizedes tapasztalatok iránymutatásként szolgálhatnak ezen erőforrással kapcsolatos intézkedések optimalizált megtervezéséhez. Rámutathatnak a szociális munkás munkavállalókkal kapcsolatos negatív, problematikus tapasztalatok, ellenállás mögött húzódó élményekre, és az azokat részben megalapozó munkáltatói döntésekre, munkakörülményekre annak érdekében, hogy az ilyen helyzeteket meg lehessen elözni, illetve jobban lehessen kezelni az esetleges beavatkozásokat.

Szakmai összejövetelek, konferenciák mentálhigiénés tárgya gyakran a kiégés és annak kezelése. Az előadások - melyek számos elméleti és gyakorlati statisztikai alapot nyújtanak a 
folyamat hátteréről, jellegéről, formáiról és elterjedtségéről - workshopokkal egészülhetnek ki, ahol ezek a gyakorlatból származó, mégis személyesebb visszacsatolások állnak rendelkezésre, gondolatébresztőként, problémaindító gyanánt. Az eredményekből kiderül, hogy a különböző ágazatokban, munkahelyeken, beosztásokban eltöltött hosszú idő a kiégés eltérő kockázatát hordozza. Az ilyen, érzelmileg kiélezettebb, pszichoszociális helyzeteket sokszor a változás oldja fel, sőt a megkérdezett szakemberek is - kevés kivétellel - ezt látják megoldásnak. Ezért javasolható, hogy a szakmában legyen meg az automatikus rotáció lehetősége úgy a kiégés megelőzése, mint a pályaelhagyás megelőzése, a fluktuáció csökkentése érdekében. A kvázi rotáció (fluktuáció) az erősen elnőiesedett pálya elején egyébként is megtörténik: a fiatal nők szülni mennek (1-2-3) alkalommal, amely többször több év „,pihenést” jelenthet. Ez hasznos, mert az érintettek számára felüdülési lehetőséget hordoz. Az elfáradt, vagy más irányba nyitni akaró szociális munkások számára azonban egy univerzálisabb megoldás igénye felé mutat. A szociális munka sokszínü, és ez némiképp segítene ezt megélni a gyakorlatban.

Ezt követően lehetne kiállni a nyilvánosság elé, és mintegy ismeretterjesztés-szerüen meg- és bemutatni magunkat, a szakmánkat. Végül, ha sikerül ilyen - szigorúan a szakmával kapcsolatos - üzeneteket (nem kevésbé pályapéldákat) rendszeresen a nyilvánosság számára küldeni, ott megjelenni, akkor érhetnénk el azt az ingerküszöböt, amelytől kezdve szociális munkás szakmáról beszélhetnének az emberek. ${ }^{6}$ Elsősorban egy ilyen helyzet adhat alkalmat arra, hogy a mindenkori döntéshozók szemében tényezökké váljunk, akikkel párbeszédben kell és érdemes szakpolitikát kialakítani.

Az eredményekből kitünik, hogy egy pályastabilitásnak alárendelt szociális munkás szakmapolitika - amely a mentálhigiénés jóllétet támogató, kiégést megelőző intézkedéseken túl a versenyszféra fizetéseihez közelíti a kereseteket, és szakmailag biztosítható minőségü munkakörülményeket teremt -, olyan szakembert bocsát ki, akinek szakember voltával, magas színvonalú szakmai tevékenységével tartósabban számolhat. A munkát hatékonyabbá teheti az e célokat elősegítő rotációs lehetőség vagy az alkotói szabadság valamilyen, a szférára adaptálható formája, valamint egy esetleges, a férfiak szakmán belüli arányát javító intézkedés. Mindezek együtt a tartósan jó színvonalú munka mellett a táppénzes állományban töltött időt is minimalizálnák, és a hatékonyságot, a szakma szükséges határozottabb fellépését növelnék.

Mindent összevetve elsődlegesen a szakma folyamatos kifelé kommunikálására van szükség, ingerré kell válni, és annak kell tudni maradni!

\section{Javaslatok}

\footnotetext{
${ }^{6}$ E célok több szegmensét is felsorolja Szabó Lajos, melyek közül kettőt tartok a legfontosabbnak: „Nagy figyelmet kell fordítani a szociális szakmák megismertetésére, a közvélemény formálására. [...] az értékek megerősítésére, a szakmai identitás és önkép pozitív alakítására” (http 4).
} 
Tudjuk, hogy vannak munkahelyek, amelyek a szociális munkás szakmai müködése szempontjából optimálisak, inspirálóak, és bizony vannak az országban, ahol a munkát folyamatos szociális munkás szerepkonfliktusok és elbizonytalanító kompromisszummérlegelések kísérik. Különös dilemma, hogy míg a képzőintézmények a szakmai szocializáció korai szakaszában igyekeznek a hallgatókat a „szakmaiabban” müködő terepek felé terelni, addig a diplomát szerző fiatalok jelentős része a kevésbé (vagy nagyon) „szakmaiatlan” terepeken kénytelen elhelyezkedni. Emiatt célszerü lenne a szakmára képző intézményeknek nyilvánosan megfogalmaznia és megtanítania a hallgatók részére legalábbis érdemes lenne rendszerezettebb módon megkísérelniük -, hogy az adott terep(típus) körülményei, korlátai és lehetőségei között mit kell, lehet, érdemes tennie.

Álláspontom szerint sokat javítana a szakma helyzetén, ha több férfi lenne az erősen elnőiesedett szakmában, egalizáltabb arányban. Ha több férfi dolgozna a szociális szférában, az többek között a szakma önképének, önazonosságának és önérvényesítésének helyzetén is javítana. (Nemzetgazdasági, helyi foglalkoztatási és munkaszervezési szempontból is kedvezőbb lenne a férfiak nagyobb jelenléte a szakmában, mert az anyáknál nagyságrendekkel kevesebbszer mennének gyesre, gyedre, illetve a gyermek után járó táppénzes állományba.) Ehhez a (diplomás) szociális munkások fizetése családfenntartó funkcióval kell bírjon.

A külső szakmakép, transzparencia javulása szempontjából fontos az újonnan strukturált univerzális iskolai szociálismunkás-hálózat körvonalazódása, felfejlődése. A lefedettség javítása annak ígéretét is hordozza, hogy teret, de legalábbis utat enged a későbbiekben a segítö-és szociális munkás értékek közvetítésében (a gyermekek, a családok, a pedagógusok felé egyaránt), a jelenleginél elterjedtebbé válásában, legitimációjában. Ez egy fokozottabb kihívás az iskolai szociális munkásoknak a tekintetben, hogy a lehetőségeikhez képest még szakszerübben, „szakmaiabban” igyekezzenek müködni.

A kiégés megelőzése végett mérlegelni kellene az egyéni szupervízió minden szociális munkás számára való foglalkoztatási típusú garantálását, amennyiben az országban nagy egyenlőtlenségek tapasztalhatók a hozzáférésben.

A képzés és a gyakorlat együttes hatására kialakuló problémaérzékenységünket - végső soron a kliensek érdekében is - használjuk a magunk problémáinak észlelésére és lehetőség szerinti megoldására! Több, tartósabb és nehezen megoldhatónak tünő problémával rendelkező társadalmi csoport kapcsán hamar felmerül a bölcs és igen szakmai javaslat: Kérdezzük meg öket, magukat! Hát ezúttal kérdezzük meg magunkat!

Az egyik interjúalany gondolatai a szakma számára is hasznosak lehetnek: „Szerintem magunkat tisztelni kell, szeretni kell! Pont azokat a dolgokat kell magaddal szemben is alkalmazni, amit amúgy elvársz másoktól, meg amit adni tudsz másoknak!”(Júlia, 43) 


\section{Irodalomjegyzék}

BUDAI I. (2007): „Megközelítések a szociális munkás-képzés fejlesztéséhez II.” Esély. 84109.

FÓNAI M., KISS J., FÁBIÁN G. (1999): „Szociális munkás szakos hallgatók pályaképének néhány eleme." Esély. 114-134.

FÓNAI M., PATTYÁN L., SZOBOSZLAI K. (2001): „Szociális munkások pályaképének néhány eleme." Esély. 89-109.

GYŐRI P. (1996): „Egy szakma születése - gyorsfénykép magunkról.” Esély. 57-74.

GYÖRI P. (2014): „Néhány szubjektív gondolat a szociális szakmáról.” Esély.74-78.

HORVÁTH Á., LÉVAI K. (1996): „Szociális munkások (I. rész).” Esély. 71-87.

HORVÁTH Á., LÉVAI K. (1996): „Szociális munkások (II. rész).” Esély. 33-56.

KÁDÁR S. (1994): „A jó szociális munkás ismérvei - szubjektív megközelítéssel.” Esély. $116-123$.

KOZMA J. (1994): „Milyen a jó szociális munkás, vagy ki tud démont űzni?” Esély. 63-70.

KOZMA J. (1996): „Szürke minden teória...” Esély. 101-116.

NAGY K. (2011): „„»Bizonytalanok « és »próbálkozók«. A szociális képzések hallgatóinak karaktertípusai és a képzés jelentősége a szakmai szocializációban.” Esély.100-116.

NAGY K. (2003): „Pályaorientációs vizsgálatok szociális munkások körében.” Szociális munka: a Szociális Munka Alapítvány folyóirata. 27-47.

PÉK I. (2000): „Merre tovább szociális munkások?” Szociális munka: a Szociális Munka Alapitvány folyóirata. 99-124.

PILINSZKI A., BÉRES O., SIPOS B., ITTZÉS G. (2014): „Mit értékelnek a szociális munkások? Mesterképzésben részt vevő szociális munkások értékrendjének sajátosságai.” Esély. 87-94.

SEIDMAN I. (2002): Az interjú, mint kvalitatív kutatási módszer. Müszaki Könyvkiadó, Budapest.

SZOBOSZLAI K. (2014): „A szociális munka a változások tükrében: kik vagyunk, hol tartunk és mit kellene tennünk?” Esély. 87-94. 


\section{Internetes források}

http:// 1. BASS L., MÁRTON I. (2005): A szociális munkások helyzete ma.pdf. In Szociális Szakmai Szövetség honlapja, http://www.3sz.hu/tartalom/szocialis-munka (látogatva: 2018. 08. 07.).

http:// 2. B. TALYIGÁS K., HEGYESI G. (2014): Honnan indult a szociális munka oktatása és gyakorlata idehaza, és hol tart most? Szubjektív áttekintő és köszöntő. In Párbeszéd - szociális munka folyóirat, Vol. 1. (2014.) No. 1-2. http://parbeszed.lib.unideb.hu/cikk/cikk/551a4bcae814d (látogatva: 2018. 08. 07.).

http:// 3. HORVÁTH-LINDBERG J. (2016): Gyakorlat, tapasztalat és reflexió: egy tereptanár gondolatai. In Párbeszéd - szociális munka folyóirat, Vol. 3. (2016.) No. 1. http://parbeszed.lib.unideb.hu/cikk/cikk/56f505d60aabc (látogatva: 2018. 10. 19.).

http:// 4. SZABÓ L. (2014): A szakmai kultúra és az intézményi kultúra, valamint az intézményi és társadalmi környezet szerepe a szociális munkában. In Párbeszéd - szociális munka folyóirat, Vol. 1. (2014.) No. 1-2. http://parbeszed.lib.unideb.hu/cikk/cikk/551a4e308904a (látogatva: 2018. 08. 10.). 